\title{
An insight into the isolation, enumeration, and molecular detection of Listeria monocytogenes in food
}

\author{
Jodi Woan-Fei Law ${ }^{1 \dagger}$, Nurul-Syakima Ab Mutalib²', Kok-Gan Chan ${ }^{3}$ and Learn-Han Lee ${ }^{1 *}$ \\ ${ }^{1}$ Biomedical Research Laboratory, Jeffrey Cheah School of Medicine and Health Sciences, Monash University, Bandar \\ Sunway, Malaysia, ${ }^{2}$ UKM Medical Molecular Biology Institute, UKM Medical Centre, Kuala Lumpur, Malaysia, ${ }^{3}$ Division of \\ Genetics and Molecular Biology, Institute of Biological Sciences, Faculty of Science, University of Malaya, Kuala Lumpur, \\ Malaysia
}

OPEN ACCESS

Edited by:

Maria Schirone,

University of Teramo, Italy

Reviewed by:

Qiaobin Xiao,

Cornell University, USA Juan Aguirre

Food Safety Adviser Chile, Chile

Paula Teixeira,

Universidade Católica Portuguesa

Portugal

${ }^{*}$ Correspondence:

Learn-Han Lee

lee.learn.han@monash.edu;

leelearnhan@yahoo.com

${ }^{\dagger}$ These authors have contributed equally to this work.

Specialty section:

This article was submitted to

Food Microbiology,

a section of the journal

Frontiers in Microbiology

Received: 20 August 2015

Accepted: 20 October 2015

Published: 03 November 2015

Citation:

Law JW-F, Ab Mutalib N-S, Chan K-G and Lee L-H (2015) An insight into the isolation, enumeration, and molecular detection of Listeria monocytogenes in food. Front. Microbiol. 6:1227.

doi: 10.3389/fmicb.2015.01227
Listeria monocytogenes, a foodborne pathogen that can cause listeriosis through the consumption of food contaminated with this pathogen. The ability of $L$. monocytogenes to survive in extreme conditions and cause food contaminations have become a major concern. Hence, routine microbiological food testing is necessary to prevent food contamination and outbreaks of foodborne illness. This review provides insight into the methods for cultural detection, enumeration, and molecular identification of L. monocytogenes in various food samples. There are a number of enrichment and plating media that can be used for the isolation of $L$. monocytogenes from food samples. Enrichment media such as buffered Listeria enrichment broth, Fraser broth, and University of Vermont Medium (UVM) Listeria enrichment broth are recommended by regulatory agencies such as Food and Drug Administration-bacteriological and analytical method (FDA-BAM), US Department of Agriculture-Food and Safety (USDAFSIS), and International Organization for Standardization (ISO). Many plating media are available for the isolation of $L$. monocytogenes, for instance, polymyxin acriflavin lithiumchloride ceftazidime aesculin mannitol, Oxford, and other chromogenic media. Besides, reference methods like FDA-BAM, ISO 11290 method, and USDA-FSIS method are usually applied for the cultural detection or enumeration of $L$. monocytogenes. most probable number technique is applied for the enumeration of $L$. monocytogenes in the case of low level contamination. Molecular methods including polymerase chain reaction, multiplex polymerase chain reaction, real-time/quantitative polymerase chain reaction, nucleic acid sequence-based amplification, loop-mediated isothermal amplification, DNA microarray, and next generation sequencing technology for the detection and identification of $L$. monocytogenes are discussed in this review. Overall, molecular methods are rapid, sensitive, specific, time- and labor-saving. In future, there are chances for the development of new techniques for the detection and identification of foodborne with improved features.

Keywords: Listeria species, isolation, enumeration, molecular detection, foodborne pathogens 


\section{INTRODUCTION}

Listeria monocytogenes has become an important foodborne pathogen and it can be found in a variety of foods which include raw foods and processed foods (Gasanov et al., 2005; Janzten et al., 2006; Liu, 2006; Jeyaletchumi et al., 2010a; Välimaa et al., 2015). L. monocytogenes has been a serious threat to the food industry due to its ability to survive the most common food processing conditions such as extreme $\mathrm{pH}$, high salt concentration, low water activity, and refrigeration temperatures (Liu, 2006; Zunabovic et al., 2011; Jadhav et al., 2012). It is known that L. monocytogenes can be eliminated or reduced by pasteurization process because it cannot survive pasteurization temperatures in food processing (Jadhav et al., 2012). For instance, a study conducted by Murphy et al. (2003) showed that hot water pasteurization and steam pasteurization resulted in a $7 \log _{10}(\mathrm{CFU} / \mathrm{g})$ reduction of L. monocytogenes in inoculated single packaged fully cooked chicken breast fillets, $227 \mathrm{~g}$ packaged fully cooked chicken strips and $454 \mathrm{~g}$ packaged fully cooked chicken strips when pasteurized at $90^{\circ} \mathrm{C}$ for 5,25 , and $35 \mathrm{~min}$, respectively. However, post-processing or post-pasteurization contamination by L. monocytogenes may occur due to crosscontamination or biofilms (Jadhav et al., 2012). L. monocytogenes can attach to food contact surfaces such as stainless steel and polystyrene during food processing and form biofilms which is important for their survival in hostile environments (Jadhav et al., 2012; Da Silva and De Martinis, 2013; Välimaa et al., 2015). Biofilms may persist for a long period of time and they can tolerate high concentrations of disinfectants, sanitizers, and antimicrobials (Välimaa et al., 2015). Hence, this may result in the contamination of food contact surfaces which then lead to higher risk of food contamination during and/or after processing. Food contaminated with $L$. monocytogenes has posed a great concern to the food industry as it can cause serious infection known as listeriosis when ingested and it is also one of the causes of recalls which may result in large economic losses (Jemmi and Stephan, 2006). Thus, microbiological food testing is important to ensure the safety of food products (Dwivedi and Jaykus, 2011; Välimaa et al., 2015).

\section{DETECTION AND IDENTIFICATION OF Listeria monocytogenes}

\section{Enrichment Media and Selectivity}

There are various selective enrichment and plating media that have been developed and utilized for the isolation and detection of L. monocytogenes in food and environmental samples. As required by majority of the regulatory agencies, the isolation methods must be able to detect one Listeria organism per $25 \mathrm{~g}$ of food. In order to achieve this sensitivity, enrichment methods are required to allow the organism to grow and reach

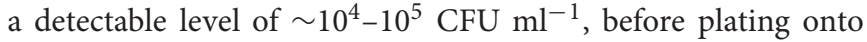
selective media and confirmation of cultures. Antimicrobial agents are employed in enrichment and plating media to suppress competing microflora as Listeria cells are slow growing and can be rapidly out-grown by competitors. The most common selective agents are acriflavine, nalidixic acid, and cycloheximide (Beumer and Hazeleger, 2003; Gasanov et al., 2005; Janzten et al., 2006; Jeyaletchumi et al., 2010a). The function of acriflavine is to inhibit the growth of other Gram-positive bacteria and it is often used in combination with other selective agents, for instance, polymyxin B-sulfate, cycloheximide, potassium thiocyanate, and nalidixic acid. Nalidixic acid is used for the inhibition of Gram-negative bacteria while cycloheximide is used for the inhibition of fungi (Beumer and Hazeleger, 2003; Janzten et al., 2006; Jeyaletchumi et al., 2010a). Besides, there are other antimicrobials that are usually added into the media such as broad-spectrum ceftazidime and moxalactam as well as lithium chloride (Janzten et al., 2006).

In addition, esculin is an important carbohydrate that is usually incorporated in Listeria enrichment and plating media (Bush and Donnelly, 1992; Janzten et al., 2006; Jeyaletchumi et al., 2010a). All Listeria sp. are capable of esculin hydrolysis and this process will result in the formation of an intense black color in the media. This is due to the presence of esculin and ferric iron in the media, in which the ferric iron forms complex with 6,7-dihidroxycoumarin, the product of esculin cleavage by $\beta$-Dglucosidase, resulting in a black precipitate (Fraser and Sperber, 1988; Janzten et al., 2006; Jeyaletchumi et al., 2010a). Hence, cultures that produce an intense black color indicate the presence of Listeria.

The regulatory agencies have recommended several selective enrichment media for L. monocytogenes such as buffered Listeria enrichment broth (BLEB), Fraser broth, and University of Vermont Medium (UVM) Listeria enrichment broth. BLEB is recommended in the US Food and Drug Administration (FDA) bacteriological and analytical method (BAM) for the isolation and identification of L. monocytogenes. BLEB is a modification of the formula by Lovett et al. (1987), in which disodium phosphate is added into the medium to increase the buffering capacity of the medium, thus, resulting in the improvement of enrichment properties. Selective agents which include acriflavine, cycloheximide, and nalidixic acid are added into the medium after an initial $4 \mathrm{~h}$ of non-selective pre-enrichment (Magalhães et al., 2014).

University of Vermont Medium Listeria enrichment broth is recommended in the US Department of Agriculture-Food and Safety (USDA-FSIS) method for the isolation and detection of L. monocytogenes. UVM is based on the formulation of Donnelly and Baigent (1986). This enrichment broth is suggested as the primary enrichment broth for the recovery of heatinjured L. monocytogenes. Nalidixic acid and acriflavine are the selective agents added into the medium (Magalhães et al., 2014).

International Organization for Standardization (ISO) 11290 method has suggested the use of Fraser broth for the selective enrichment of L. monocytogenes in food and environmental samples. Fraser broth is based on the formulation of Fraser and Sperber (1988) whereby it is a modification of USDA secondary enrichment broth by the addition of ferric ammonium citrate and lithium chloride. The selective agents added into Fraser broth are nalidixic acid and acriflavine (Magalhães et al., 2014). 
Presumptive L. monocytogenes can be detected within 48 h by using Fraser broth (Fraser and Sperber, 1988).

The frequently recommended selective differential plating media by FDA-BAM, ISO, and USDA for the isolation of Listeria sp. are PALCAM (polymyxin acriflavin lithium-chloride ceftazidime aesculin mannitol) and Oxford (Zunabovic et al., 2011). PALCAM and Oxford are both useful for the isolation of Listeria sp. from food samples with injured Listeria cells and/or rich in competitive microflora (El Marrakchi et al., 2005). PALCAM agar was initially developed by Van Netten et al. (1989) for the detection and enumeration of L. monocytogenes and other Listeria sp. from food samples. PALCAM agar consists of Columbia Blood Agar with $23.0 \mathrm{~g} / \mathrm{L}$ protease peptones, $0.5 \mathrm{~g} / \mathrm{L}$ glucose, $1.0 \mathrm{~g} / \mathrm{L}$ starch, $3.0 \mathrm{~g} / \mathrm{L}$ yeast extract, and $5.0 \mathrm{~g} / \mathrm{L}$ sodium chloride. The selectivity of this medium is achieved by the addition of $15 \mathrm{~g} / \mathrm{L}$ lithium chloride, $0.01 \mathrm{~g} / \mathrm{L}$ polymyxin $\mathrm{B}, 0.005 \mathrm{~g} / \mathrm{L}$ acriflavine, and $0.02 \mathrm{~g} / \mathrm{L}$ ceftazidime. The differentiation on PALCAM agar is based on (1) esculin hydrolysis, addition of $0.8 \mathrm{~g} / \mathrm{L}$ esculin and $0.5 \mathrm{~g} / \mathrm{L}$ ferric salt and (2) mannitol fermentation, addition of $10 \mathrm{~g} / \mathrm{L}$ mannitol and $0.08 \mathrm{~g} / \mathrm{L}$ phenol red (Van Netten et al., 1989; Magalhães et al., 2014). PALCAM agar plated with bacteria is usually incubated for $24-48 \mathrm{~h}$ at $37^{\circ} \mathrm{C}$ (Jamali et al., 2013; Ajay Kumar et al., 2014; Osman et al., 2014). Since all Listeria sp. can hydrolyze esculin, they are visually confirmed by a blackening of the medium and their colonies are about $2 \mathrm{~mm}$ diameter, graygreen in color with a black sunken center and a black halo. Occasionally, Enterococcus sp. or Staphylococcus sp. may grow on PALCAM agar. However, they can be distinguished from Listeria sp. via mannitol fermentation. Mannitol fermentation causes a color change in the colony and/or surrounding medium from gray or red to yellow due to the production of acids. Colonies of these mannitol fermenting organisms are yellow with a yellow halo or gray with a brown-green halo (Van Netten et al., 1989; Ajay Kumar et al., 2014; Osman et al., 2014).

Oxford agar was initially developed by Curtis et al. (1989) for the isolation of L. monocytogenes from clinical specimens. Oxford agar has been extensively used in many studies for the isolation and detection of L. monocytogenes from various food samples (Pinto et al., 2001; Rudol and Scherer, 2001; Gudbjörnsdóttir et al., 2004; Mena et al., 2004; Alessandria et al., 2010). Oxford consists of Columbia Blood Agar with $23 \mathrm{~g} / \mathrm{L}$ protease peptones, $5.0 \mathrm{~g} / \mathrm{L}$ sodium chloride, and $1.0 \mathrm{~g} / \mathrm{L}$ starch. The selectivity of Oxford is achieved by the addition of $15 \mathrm{~g} / \mathrm{L}$ lithium chloride, $0.005 \mathrm{~g} / \mathrm{L}$ acriflavine, $0.02 \mathrm{~g} / \mathrm{L}$ colistin sulfate, $0.4 \mathrm{~g} / \mathrm{L}$ cycloheximide, $0.002 \mathrm{~g} / \mathrm{L}$ cefotetan, and $0.01 \mathrm{~g} / \mathrm{L}$ fosfomycin. The differentiation of Listeria sp. on Oxford agar is based on esculin hydrolysis which is aided by the addition of $1 \mathrm{~g} / \mathrm{L}$ esculin and $0.5 \mathrm{~g} / \mathrm{L}$ ferric ammonium citrate into the agar (Curtis et al., 1989; Janzten et al., 2006; Magalhães et al., 2014). Oxford agar is incubated for $24-48 \mathrm{~h}$ at $37^{\circ} \mathrm{C}$ after plating (Curtis et al., 1989; Alessandria et al., 2010). After $24 \mathrm{~h}$ of incubation, L. monocytogenes colonies are olive-green with a black halo. After $48 \mathrm{~h}$ of incubation, L. monocytogenes colonies are about $2-3 \mathrm{~mm}$ in diameter, the color turns darker with a black sunken center and surrounded by black zones. Other Listeria sp. colonies have a similar appearance to L. monocytogenes colonies. Colonies of other Listeria sp. are black with a black halo after $24 \mathrm{~h}$ of incubation and they remain the same after $48 \mathrm{~h}$ of incubation but with a sunken center (Curtis et al., 1989; Magalhães et al., 2014). Staphylococcus sp. may grow on Oxford agar occasionally and their colonies are yellow in color, irregular in size as well as shape (Curtis et al., 1989). A variation of Oxford agar has been developed and it is known as Modified Oxford Agar (MOX). MOX is recommended for the isolation and identification of L. monocytogenes from processed meat and poultry products whereas Oxford agar is recommended for the isolation of L. monocytogenes from enrichment broth cultures (Magalhães et al., 2014).

The main limitation of PALCAM and Oxford is the inability to distinguish between L. monocytogenes from nonpathogenic Listeria sp. (El Marrakchi et al., 2005; Zunabovic et al., 2011). Hence, these plating media are not able to provide a rapid detection of $L$. monocytogenes from foods. This has led to the development of chromogenic media which can improve the isolation of L. monocytogenes as they are able to differentiate $L$. monocytogenes and/or pathogenic Listeria sp. from other non-pathogenic Listeria sp. (Beumer and Hazeleger, 2003). Chromogenic media detect essential determinants of pathogenicity of Listeria sp. and majority of these media are commercially available as ready-to-use plates (Janzten et al., 2006; Zunabovic et al., 2011). Besides, presumptive L. monocytogenes can be identified after $24 \mathrm{~h}$ by using chromogenic media (Jeyaletchumi et al., 2010a). Several studies have demonstrated that chromogenic media such as Agar Listeria according to Ottaviani and Agosti (ALOA) and CHROMagar $^{\mathrm{TM}}$ Listeria are more sensitive, specific, time and cost saving in L. monocytogenes detection compared to nonchromogenic media such as PALCAM and Oxford (Vlaemynck et al., 2000; Hegde et al., 2007; Jamali et al., 2013).

Agar Listeria according to Ottaviani and Agosti is a chromogenic medium developed by Ottaviani et al. (1997) for the isolation of Listeria sp. and specific detection of L. monocytogenes. The selectivity of ALOA is achieved by the addition of lithium chloride and antimicrobials such as ceftazidime, polymyxin B, nalidixic acid, and cycloheximide (Beumer and Hazeleger, 2003; Magalhães et al., 2014). The differentiation of Listeria sp. on ALOA is achieved by the incorporation of chromogenic substrate (5-bromo-4-chloro-3indolyl- $\beta$-D-glucopyranoside, $\mathrm{X}$-glucoside) in the medium for the detection of $\beta$-D-glucosidase activity, common to all Listeria sp. The differentiation of L. monocytogenes from other Listeria $\mathrm{sp}$. is based on the production of phosphatidylinositol-specific phospholipase C (PI-PLC) which is encoded by the virulence gene plcA present in L. monocytogenes. ALOA detects PI-PLC that is present in L. monocytogenes and in some strains of $L$. ivanovii through the hydrolysis of $\mathrm{L}-\alpha$-phosphatidylinositol in the medium by PI-PLC. This results in the production of water insoluble fatty acids and the formation of an opaque halo around the colonies. In ALOA, all Listeria sp. produce blue-green colonies and pathogenic Listeria sp. such as L. monocytogenes and L. ivanovii produce blue-green colonies with an opaque halo (Ottaviani et al., 1997; Beumer and Hazeleger, 2003; Janzten et al., 
2006; Jeyaletchumi et al., 2010a; Zunabovic et al., 2011; Magalhães et al., 2014; Park et al., 2014).

CHROMagar ${ }^{\mathrm{TM}}$ Listeria (Becton Dickson Diagnostics) is one of the variations of ALOA that have been developed for the isolation and detection of L. monocytogenes. On CHROMagar ${ }^{\mathrm{TM}}$ Listeria, colonies of L. monocytogenes are blue with a white halo and colonies of other Listeria sp. are blue without halo. Some strains of $L$. ivanovii may grow on CHROMagar ${ }^{\mathrm{TM}}$ Listeria and they also produce blue colonies with a white halo (Magalhães et al., 2014). Additional variations of ALOA and commercially available media include Biosynth Chromogenic Medium (BCM) L. monocytogenes detection system (Biosynth), Compass L. mono (Biokar Diagnostics), Brilliance ${ }^{\mathrm{TM}}$ Listeria Agar (Oxoid) and chromID Ottaviani Agosti Agar (bioMérieux; Janzten et al., 2006; Zunabovic et al., 2011).

Rapid' L. mono agar is a chromogenic medium that operates differently than ALOA. Rapid' L. mono agar detects PI-PLC that is present in L. monocytogenes and L. ivanovii through the hydrolysis of a different substrate by PI-PLC, which is 5-bromo4-chloro-3-indolyl-myo-inositol-1-phospjhate (X-IP). Cleavage of X-IP by PI-PLC results in the production of blue colonies. Hence, L. monocytogenes and L. ivanovii appear as blue colonies on Rapid' L. mono agar. Furthermore, the addition of xylose into the medium enables the differentiation of $L$. monocytogenes from $L$. ivanovii. The ability of $L$. ivanovii to metabolize xylose results in the production of blue colonies with a yellow halo. As for L. monocytogenes, the colonies produced are blue without halo due to the inability to metabolize xylose. Other Listeria sp. that grow on Rapid' L. mono agar will appear as white colonies with or without a yellow halo (Janzten et al., 2006; Zunabovic et al., 2011; Magalhães et al., 2014).

In general, chromogenic media are able to isolate and distinguish $L$. monocytogenes from other Listeria sp. and thus allowing a more rapid detection of L. monocytogenes. However, the sensitivity and specificity of the culture media may be affected by the types of food matrices (Andritsos et al., 2013). For instance, the study conducted by Aragon-Alegro et al. (2008) indicated that the sensitivity and specificity of CHROMagar ${ }^{\mathrm{TM}}$ Listeria for the detection of L. monocytogenes in sliced cooked ham (56.2\% sensitivity and $73.6 \%$ specificity), minced beef meat (92.7\% sensitivity and $76.8 \%$ specificity) and frankfurters (91.2\% sensitivity and $84.2 \%$ specificity) were different. Hence, there are no particular medium which is perfect for the isolation of L. monocytogenes from various food samples (Churchill et al., 2006; Andritsos et al., 2013).

\section{Cultural Detection and Enumeration of Listeria monocytogenes}

Traditionally, the detection and identification of pathogens in foods involve the use of culture methods followed by phenotypic confirmation based on standard culture (e.g., haemolysis and phospholipase C), biochemical and immunological identification (Gasanov et al., 2005; Janzten et al., 2006). The conventional methods are simple, sensitive, inexpensive, and important when bacterial culture is required as the end result from positive samples (Churchill et al., 2006; Janzten et al., 2006; Law et al., 2015). Generally, the culture methods involve a twostage enrichment process followed by plating on a selective differential agar (Beumer and Hazeleger, 2003; Janzten et al., 2006). The procedures may vary depending on the number of cells expected in a sample and/or the official culture reference methods used. The success of culture methods depends on several factors. For instance, the amount and state of the bacteria in the sample, the selectivity of the media (balance between inhibition of competitors and inhibition of the target bacteria), electivity of the isolation medium (difference between the target bacteria and competitive microflora) and the conditions of incubation (e.g., temperature, time, and oxygen; Beumer and Hazeleger, 2003).

The food samples are homogenized prior to the two-stage enrichment process which is divided into pre-enrichment stage and selective enrichment stage that involve incubation for $\sim 24-$ $72 \mathrm{~h}$ at $30-37^{\circ} \mathrm{C}$ (Churchill et al., 2006; Janzten et al., 2006). Preenrichment is carried out in non- or half-selective enrichment medium in order to revive the injured target pathogen and to increase the amount of the target pathogen. In addition, preenrichment allows the dilution of inhibitory compounds present in foods such as preservatives and rehydration of bacterial cells sampled from dried or processed food matrices (Gasanov et al., 2005; Dwivedi and Jaykus, 2011; Jadhav et al., 2012; Välimaa et al., 2015). As for selective enrichment, it involves the use of selective medium that will increase the amount of target pathogen while suppress the growth of competing background microflora, thus, enabling the isolation and detection of the target pathogen (Dwivedi and Jaykus, 2011; Välimaa et al., 2015). Selective and differential plating is carried out after the two-stage enrichment process. The analysis is completed if there are no typical colonies can be observed on the selective differential agar and the results are reported as negative. If presumptive positive colonies are isolated, further tests are required to confirm the isolated pathogen such is described below (Jeyaletchumi et al., 2010a; Dwivedi and Jaykus, 2011; Välimaa et al., 2015).

The well-known culture reference methods for the isolation and detection of L. monocytogenes in foods are the FDA-BAM, ISO 11290 method, and USDA-FSIS method. These methods are recommended for the detection of L. monocytogenes from different food matrices and they utilize different enrichment media as well as plating media. Besides, the incubation time and temperature employed by each culture reference method are slightly different (Gasanov et al., 2005; Churchill et al., 2006; Janzten et al., 2006; Jeyaletchumi et al., 2010a; Välimaa et al., 2015). Numerous researchers have employed these culture reference methods for the investigation of $L$. monocytogenes in foods (Jeyaletchumi et al., 2010a; Goh et al., 2012; Lambertz et al., 2012; Jamali et al., 2013; Kramarenko et al., 2013; Wang et al., 2013; Osman et al., 2014). The culture reference methods are summarized in Table 1.

The qualitative information of the pathogen is provided by conventional methods. As for the quantitative information of the pathogen, it is required if the pathogen is detected in the food sample. The enumeration of the level of L. monocytogenes contamination in food sample can be done according to the ISO 11290-2 method (ISO, 2004b) and the protocols mentioned in FDA-BAM as well as USDA-FSIS method (Table 1). Besides, 
TABLE 1 | Summary of each culture reference method for the isolation and detection of $L$. monocytogenes in foods and the detection limit of each method.

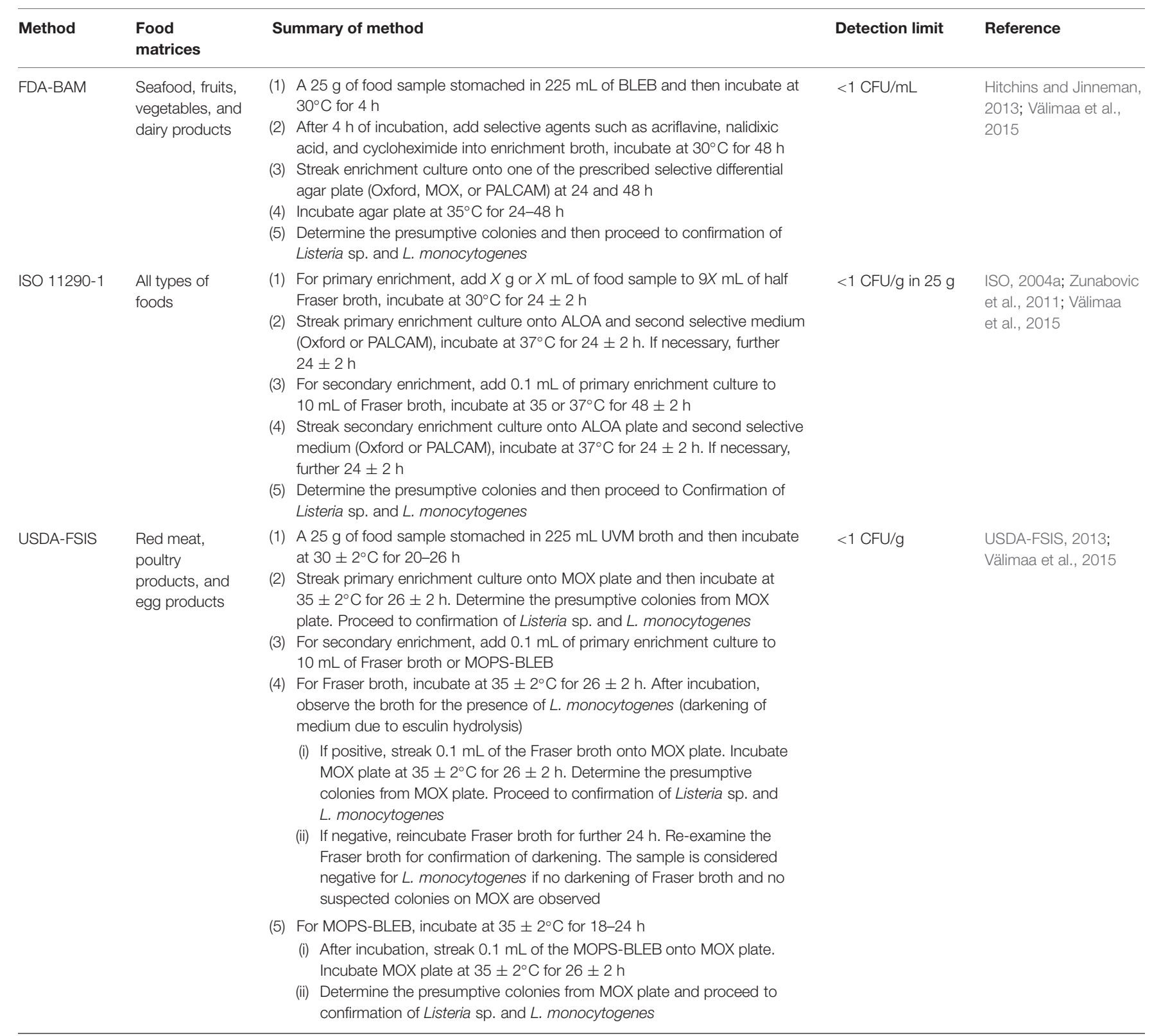

the FDA and USDA have issued Compliance Policy Guides for food industry regarding the appropriate measures required to control L. monocytogenes in food and prevent contamination of food with L. monocytogenes (Kraiss, 2008). Enumeration of L. monocytogenes in food is important because an initial contamination as few as $1 \mathrm{CFU} / 100 \mathrm{~g} L$. monocytogenes can cause the food unsafe in 32 days, while $10 \mathrm{CFU} / \mathrm{g}$ L. monocytogenes can cause the food unsafe in 8 days (Salvat and Fravalo, 2004). L. monocytogenes is able to grow over a wide range of temperatures, from around -0.4 to $45^{\circ} \mathrm{C}$ with an optimum temperature of $37^{\circ} \mathrm{C}$ (International Commission on Microbiological Specifications for Foods [ICMSF], 1996). Hence, this may cause the prevalence of L. monocytogenes in food to increase and reach unsafe levels during storage periods or long holding time before retailing. The infectious dose of L. monocytogenes for healthy or susceptible individuals has not been established, however, it is estimated to be $\sim 10^{7}-10^{9}$ CFU in healthy individuals and $10^{5}-10^{7} \mathrm{CFU}$ in susceptible individuals such as immunocompromised people or pregnant women (Farber et al., 1996; Smith et al., 2003). In order to enumerate the level of food sample contamination by presumptive $L$. monocytogenes, the primary enrichment broth is quantified prior to incubation, by direct spread plate count on chromogenic media (Hitchins and Jinneman, 2013). If the level of contamination is low, the enumeration of L. monocytogenes is done by the most probable number (MPN) 
technique (Janzten et al., 2006; Jeyaletchumi et al., 2010a; Hitchins and Jinneman, 2013). Besides, some samples may contain particulate material that will interfere with plate count enumeration methods. Hence, MPN technique is applied for these types of samples (Sutton, 2010). MPN technique allows the estimation of population density of viable microorganisms in a sample through replicate liquid broth growth in 10-fold dilutions (Sutton, 2010; Letchumanan et al., 2014). The theoretical basis for MPN technique is to dilute the sample to some extent that inocula in the tubes will occasionally contain viable organisms. A reasonably accurate estimation of the most probable number of cells in the sample can thus be achieved by replicates and dilution series (Sutton, 2010). The FDA-BAM has described 10fold serial dilution of sample in BLEB with the use of three or more tube MPN culture procedure on each dilution. The samples are incubated at $30^{\circ} \mathrm{C}$ for $48 \mathrm{~h}$, followed by streaking on selective agar medium (Hitchins and Jinneman, 2013). L. monocytogenes can be directly enumerated if chromogenic media is used after MPN enrichment (Janzten et al., 2006; Jeyaletchumi et al., 2010a).

Most probable number technique is more sensitive as compared to direct plating, however, it is more labor intensive and it requires $\sim 7$ days to complete the identification (Janzten et al., 2006; Jeyaletchumi et al., 2010a; Dwivedi and Jaykus, 2011). In MPN technique, the use of selective agar media or chromogenic media may not be selective enough as they may allow the growth of other competitive background microflora, thereby causing difficulties in determining presumptive L. monocytogenes (Jeyaletchumi et al., 2010a). MPN technique combined with polymerase chain reaction (PCR) technique is developed in order to overcome these limitations. MPN-PCR technique involves the detection of a particular gene in the target bacteria by PCR instead of isolation of the target bacteria for the enumeration of the bacteria in a sample (Letchumanan et al., 2014). Hence, this technique allows the direct enumeration of L. monocytogenes in food without interference of background microflora. The enumeration of L. monocytogenes by MPN-PCR technique can be completed in 2 days and this method has higher sensitivity than the standard MPN technique (Jeyaletchumi et al., 2010a). Several researchers have reported the success of MPN-PCR technique for the enumeration of L. monocytogenes in various food samples such as fermented sausages (Martín et al., 2004), salad vegetables (Jeyaletchumi et al., 2010b), and raw chicken (Goh et al., 2012).

\section{MOLECULAR DETECTION OF Listeria monocytogenes}

The detection of $L$. monocytogenes in food samples by conventional methods is simple, sensitive, and inexpensive if compared with molecular methods (Janzten et al., 2006; Law et al., 2015). However, conventional methods are laborious and time consuming as they require more than a week for the detection and confirmation of pathogen (Dwivedi and Jaykus, 2011; Law et al., 2015; Letchumanan et al., 2015b). Due to the recent advances in molecular technology, molecular methods have been used as an alternative to culture and serological methods for food testing (Gasanov et al., 2005). The detection of a pathogen present in food by nucleic-acid based molecular methods is based on the detection of specific DNA or RNA sequences in the target pathogen. Hence, these genetic methods can provide highly accurate and reliable results as compared to phenotypic methods. Nevertheless, molecular methods require specialized instruments and highly trained personnel (Gasanov et al., 2005; Jadhav et al., 2012; Law et al., 2015). There are various molecular methods available for the detection and identification of L. monocytogenes, for instance, PCR, multiplex polymerase chain reaction ( $\mathrm{mPCR}$ ), real-time/quantitative polymerase chain reaction (qPCR), nucleic acid sequence-based amplification (NASBA), loop-mediated isothermal amplification (LAMP), DNA microarray as well as next generation sequencing (NGS) technology.

Polymerase chain reaction has been widely used for the detection of various foodborne bacterial pathogens. This method requires two single-stranded synthetic oligonucleotides or specific primers for the amplification of a specific target DNA sequence in a cyclic three steps process involving the use of a thermal cycler. The PCR amplification products are separated by agarose gel electrophoresis and visualized on the gel as bands with a DNA stain. The specific detection of the genus Listeria by PCR involves PCR primers based on the highly conserved 16S rRNA sequence present in all Listeria sp. with a resulting 938 bp amplification product (Levin, 2003; Burbano et al., 2006; Goh et al., 2012; Jamali et al., 2013). L. monocytogenes can be differentiated from other Listeria sp. by exploiting the molecular differences within the PCR amplified 16S rRNA gene, 23S rRNA gene and 16S-23S rRNA intergenic spacer regions (Wang et al., 1992; Graham et al., 1996, 1997; Sallen et al., 1996). In addition, PCR method also detects L. monocytogenes at the species level by targeting the virulence genes of the organism (Levin, 2003). Several virulence genes have been identified in L. monocytogenes and targeted for the PCR detection of the organism, for example, hly $(h l y A)$ gene codes for listeriolysin O (LLO; Deneer and Boychuk, 1991; Johnson et al., 1992; Agersborg et al., 1997; Aznar and Alarcón, 2003; Amagliani et al., 2004; Burbano et al., 2006), iap gene codes for an invasion-associated protein known as p60 (Agersborg et al., 1997; Aznar and Alarcón, 2003; Swetha et al., 2012), actA gene codes for a surface protein known as ActA which is required for intracellular bacterial propulsion and cell to cell invasion (Moriishi et al., 1998; Levin, 2003), ImaA gene codes for L. monocytogenes antigen (lmaA), which also known as Dth-18 gene codes for delayed-type hypersensitivity protein (DTH-18 factor; Wernars et al., 1991; Johnson et al., 1992; Levin, 2003), inlA gene codes for internalin A (Almeida and Almeida, 2000; Ingianni et al., 2001; Jung et al., 2003), inlB gene codes for internalin B (Pangallo et al., 2001; Jung et al., 2003), prfA gene codes for positive regulator factor A (PrFA; Simon et al., 1996), рерC codes for aminopeptidase C (Winters et al., 1999), $f b p$ gene codes for fibronectin-binding protein (Gilot and Content, 2002) and $p l c B$ Phospholipase C protein (Volokhov et al., 2002). Among these targeted genes, the hlyA gene is the most frequently chosen target gene for the PCR detection of L. monocytogenes (Aznar and Alarcón, 2003; Jadhav et al., 2012). The hlyA gene codes for a protein with pore forming activity, 
which is known as listeriolysin O. This protein is found to be essential for the virulence of L. monocytogenes as it is responsible for the lysis of phagocyte vacuole and followed by the escape of L. monocytogenes from the vacuole (Kathariou et al., 1987; Cossart et al., 1989; Levin, 2003; Liu, 2006). Besides, it has been discovered that all clinical isolates of $L$. monocytogenes have hemolytic activity due to listeriolysin $\mathrm{O}$ and thus the $h l y A$ gene is a relevant marker for the identification of L. monocytogenes (Groves and Welshimer, 1977; Golsteyn-Thomas et al., 1990).

Other than simple PCR, multiplex PCR (mPCR) is available for a more rapid detection of $L$. monocytogenes. Multiplex PCR is a variant of simple PCR in which multiple gene targets are simultaneously amplified by using several sets of specific primers in a single reaction (Liu et al., 2007). The primer design, concentration of primers, PCR buffer concentrations, quantities of DNA template, Taq DNA polymerase, balance between magnesium chloride and deoxynucleotide concentrations and cycling temperatures are very important for a successful mPCR assay (Markoulatos et al., 2002; Zhao et al., 2014; Law et al., 2015). Multiplex PCR is capable of detecting multiple virulence-associated genes of $L$. monocytogenes in a single PCR mixture. Hence, the possible failure in the detection of virulent L. monocytogenes can be prevented (Cooray et al., 1994). In the study conducted by Cooray et al. (1994), L. monocytogenes in milk samples was successfully detected by $\mathrm{mPCR}$ with primers targeting three virulence-associated genes, prfA, hlyA, and plcB. Liu et al. (2007) had developed an mPCR assay targeting inlA, inlC, and inlJ genes for the rapid species-specific and virulence-specific determination of L. monocytogenes. Besides, MPCR is employed for simultaneous detection of L. monocytogenes, Listeria sp. and other foodborne pathogens such as Salmonella sp., Escherichia coli O175:H7, Vibrio parahaemolyticus, Staphylococcus aureus, Bacillus cereus as well as Campylobacter jejuni in various food samples (Lawrence and Gilmour, 1994; Gilbert et al., 2003; Jofré et al., 2005; Germini et al., 2009; Kumar et al., 2009; Yuan et al., 2009; Zhang et al., 2009; Zarei et al., 2012; Yang et al., 2013). A novel mPCR assay that can simultaneously detect and discriminate six Listeria species including L. monocytogenes, L. grayi, L. ivanovii, L. innocua, L. welshimeri, and L. seeligeri was first developed by Ryu et al. (2013). A rapid mPCR assay for simultaneous detection of L. monocytogenes, S. aureus, E. coli O157:H7, Salmonella Enteritidis, and Shigella flexneri in meat samples was developed by Chen et al. (2012). Lee et al. (2014) had carried out mPCR assay that can simultaneously detect L. monocytogenes, B. cereus, E. coli O157:H7, V. parahaemolyticus, Salmonella sp., and $S$. aureus in ready-to-eat food samples. Furthermore, the major L. monocytogenes serovars such as $1 / 2 \mathrm{a}, 1 / 2 \mathrm{~b}, 1 / 2 \mathrm{c}$, and $4 \mathrm{~b}$ can be differentiated by mPCR targeting marker genes Imo0730, Imo1118, ORF2819, and ORF2110 (Doumith et al., 2004; Hamdi et al., 2007; Erol and Ayaz, 2011).

The development of real-time or quantitative PCR (qPCR) provides high-throughput analysis and low risk of crosscontamination since post-PCR processing for the detection of PCR products is not required (Fricker et al., 2007). Fluorescent dye such as SYBR green, hydrolysis probe such as TaqMan assays and oligonucleotide hybridization probes such as molecular beacons are used to monitor the PCR products in qPCR (Law et al., 2015). Recently, qPCR is widely used for the detection of foodborne pathogens and multiplex qPCR is also developed for this purpose. This method offers rapid and specific identification as well as quantification of $L$. monocytogenes in a variety of food samples such as soft cheese, fruit juice, fish, vegetables, salads, milk, meat, and crustaceans (Berrada et al., 2006; O'Grady et al., 2008; Kim and Cho, 2010; Garrido et al., 2013; Gianfranceschi et al., 2014). Oravcová et al. (2005) had developed a realtime $5^{\prime}$-nuclease PCR targeting a sequence of the gene actA for the identification and quantification of L. monocytogenes. In this study, TaqMan probe was used for the detection and quantification of qPCR products. Besides, Barbau-Piednoir et al. (2013) developed a combination of four qualitative SYBRgreen qPCR assays for the detection and discrimination of Listeria sp. and L. monocytogenes with high accuracy. In these assays, the iap and prs genes were targeted for detection of Listeria sp. and $h l y A$ gene was targeted for detection of L. monocytogenes. The successful detection of L. monocytogenes in fresh produce using molecular beacon-qPCR targeting the $h l y A$ gene was first reported by Liming et al. (2004). Furthermore, a novel $5^{\prime}$ exonuclease multiplex qPCR assay for the identification of six Listeria sp. including L. monocytogenes, L. seeligeri, L. ivanovii, L. welshimeri, L. grayi, and L. innocua was developed by Hage et al. (2014). In this study, two sets of triplex PCR were designed with one set identifying L. seeligeri, L. welshimeri, and L. monocytogenes and another set identifying L. ivanovii, L. grayi, and L. innocua. The Listeria species were differentiated by targeting their respective species-specific target genes and TaqMan probe was used to monitor the multiplex qPCR products.

Additionally, commercial qPCR kits for the detection of L. monocytogenes are available and this allows laboratories in food industry to adapt qPCR testing easily (Janzten et al., 2006). The examples of these commercial qPCR kits include BAX ${ }^{\circledR}$ System Real-time PCR Assay Listeria monocytogenes (DuPontQualicon), Probelia ${ }^{\circledR}$ Listeria monocytogenes PCR System (Bio-Rad), LightCycler ${ }^{\circledR}$ Listeria monocytogenes Detection Kit (Roche/Biotecon), TaqMan ${ }^{\circledR}$ Listeria monocytogenes Detection Kit (Applied Biosystems), GeneVision ${ }^{\circledR}$ Rapid Pathogen Detection System for Listeria monocytogenes (Warnex), ADIAFOOD rapid pathogen detection system for Listeria monocytogenes (AES Chemunex), CycleavePCR ${ }^{\circledR}$ Listeria monocytogenes (inlA gene) Detection Kit (TaKaRa Bio, Inc.) and iQ-Check L. monocytogenes kit (Bio-Rad Laboratories; Liming et al., 2004; Rodríguez-Lázaro et al., 2004; Becker et al., 2005; Janzten et al., 2006; Liu et al., 2012).

There is no doubt that PCR-based detection methods are rapid, highly sensitive, and specific. However, these methods require thermocycling system. Alternative methods have been developed for the amplification of nucleic acids under isothermal conditions. Two of the most commonly used isothermal nucleic acid amplification methods for the detection of foodborne pathogens are LAMP and NASBA.

Several types of LAMP assays such as multiplex LAMP, realtime LAMP, in situ LAMP and reverse-transcription LAMP have been developed and utilized for the detection of foodborne 
pathogens (Ye et al., 2011; Law et al., 2015). Studies have shown that LAMP assay has high specificity and it exhibits higher sensitivity than PCR assays in the detection of L. monocytogenes. For example, Tang et al. (2011) conducted a sensitive and specific LAMP assay for the detection of $L$. monocytogenes with primers that target the $h l y A$ gene region. In this study, the LAMP assay was evaluated against conventional PCR method for the detection of $L$. monocytogenes in food. The results indicated that LAMP assay was 100 times more sensitive than the conventional PCR assay. Besides, a real-time quantitative LAMP that amplifies the hlyA gene of L. monocytogenes was designed by Shan et al. (2012). This LAMP assay was then used to detect L. monocytogenes in four different types of retail food samples such as raw meat, vegetables, deli, and seafood. The study also proven that LAMP assay was more sensitive than PCR in the detection of L. monocytogenes. A double LAMP (dLAMP) assay was first conducted by Wu et al. (2014) for the detection of L. monocytogenes in food samples including pork, beef, chicken, mutton, shrimp, fish, and quick-frozen rice flour products. LAMP primers targeting the hlyA and iap genes of L. monocytogenes were used to ensure the dLAMP assay is more rapid, sensitive and specific. The results of this study showed that dLAMP assay was more sensitive and less time consuming as compared to normal LAMP assay. Recently, LAMP has been commercialized as kits for the detection of L. monocytogenes, for instance, Loopamp ${ }^{\circledR}$ Listeria monocytogenes Detection Kit (Eiken Chemical, Co., Ltd.) and Isothermal Master Mix (OptiGene; Wang et al., 2015).

In general, NASBA often involves in the amplification of mRNA targets under isothermal conditions (Leone et al., 1998). NASBA selectively amplifies the mRNA targets even in the presence of genomic DNA and it has been used to detect various foodborne pathogens (Simpkins et al., 2000). The main advantage of NASBA over other molecular detection methods is its ability to detect viable bacterial cells that are present in environmental samples and food samples (Simpkins et al., 2000; Cook, 2003). A highly specific NASBA system was developed by Blais et al. (1997) for the detection of L. monocytogenes with primers targeting the hlyA mRNA sequences. The NASBA system was capable of detecting low numbers of $L$. monocytogenes $(<10 \mathrm{CFU} / \mathrm{g})$ in artificially contaminated dairy and egg products after $48 \mathrm{~h}$ enrichment period. Nevertheless, false-positive results were reported and the researchers suggested that the reason for this could be due to cross-contamination of NASBA reactions with amplicons from previous amplifications performed at the same site. The post-NASBA product detection steps involving agarose gel electrophoresis, enzyme-linked gel assay, enzymatic bead-based detection and numerous probing and/or blotting techniques can be laborious. Hence, homogenous real-time NASBA that

TABLE 2 | Application of molecular methods for the detection and identification of $L$. monocytogenes in various food samples.

\begin{tabular}{|c|c|c|c|}
\hline Detection method & Gene target & Food matrix & Reference \\
\hline \multirow[t]{3}{*}{ Simple PCR } & hlyA, iap & Naturally contaminated fish samples & Swetha et al., 2012 \\
\hline & hlyA & $\begin{array}{l}\text { Naturally contaminated raw meat (chicken, beef, and fish), milk and milk } \\
\text { products (raw milk, cheese, and curd) }\end{array}$ & Khan et al., 2013 \\
\hline & act $A$ & Artificially contaminated milk, pork, and water & Zhou and Jiao, 2005 \\
\hline \multirow[t]{3}{*}{ Multiplex PCR } & iap, hly & Artificially contaminated milk & Zeng et al., 2006 \\
\hline & plcA, hlyA, actA, iap & Artificially contaminated milk & Rawool et al., 2007 \\
\hline & $16 S$ rRNA, iap & Naturally contaminated deli meat samples: pork and chicken products & Liu et al., 2015 \\
\hline \multirow{6}{*}{$\begin{array}{l}\text { Real- } \\
\text { time/quantitative } \\
\text { PCR }\end{array}$} & prfA & $\begin{array}{l}\text { Artificially contaminated raw milk, salmon, pâté, and green-veined cheese } \\
\text { Naturally contaminated fish, meat, meat products, and dairy products }\end{array}$ & Rossmanith et al., 2006 \\
\hline & lap & Artificially contaminated milk & Hein et al., 2001 \\
\hline & Hly & Artificially contaminated pork meat & Gattuso et al., 2014 \\
\hline & $\begin{array}{l}\text { 16S-23S rRNA intergenic } \\
\text { spacer regions }\end{array}$ & $\begin{array}{l}\text { Artificially contaminated soft cheese, fermented sausage, cured ham, and } \\
\text { ready-to-eat salad } \\
\text { Naturally contaminated fresh meat, fresh sausages, fermented sausages, } \\
\text { fresh cheeses, and ripened cheeses }\end{array}$ & Rantsiou et al., 2008 \\
\hline & $16 \mathrm{~S}$ rRNA & $\begin{array}{l}\text { Leafy vegetables: collard green, cabbage, lettuce, mixed parsley, chinese } \\
\text { cabbage, spring onion bunches, spinach, wild chicory, arugula, and } \\
\text { watercress }\end{array}$ & De Oliveira et al., 2010 \\
\hline & $\operatorname{in} / A$ & Artificially contaminated chicken meat & Navas et al., 2006 \\
\hline \multirow[t]{3}{*}{ LAMP } & prfA & Artificially contaminated milk & Cho et al., 2014 \\
\hline & hlyA & Artificially contaminated chicken, pork, ground beef, and milk powder & Wan et al., 2012 \\
\hline & iap & Artificially and naturally contaminated raw milk & Wang et al., 2011 \\
\hline NASBA & 16S rRNA & $\begin{array}{l}\text { Artificially contaminated chicken breast meat, soft cheese, shrimps, dry } \\
\text { sausage, minced meat (pork and beef), radish and mushrooms }\end{array}$ & Uyttendaele et al., 1995 \\
\hline DNA microarray & $\begin{array}{l}\text { Genomic DNA of } \\
\text { L. monocytogenes }\end{array}$ & Artificially contaminated milk & Bang et al., 2013 \\
\hline NGS & $\begin{array}{l}\text { Whole genome of } \\
\text { L. monocytogenes }\end{array}$ & $\begin{array}{l}\text { Deli turkey meat } \\
\text { Ready to eat meat } \\
\text { Quargel cheese }\end{array}$ & $\begin{array}{l}\text { Orsi et al., } 2008 \\
\text { Gilmour et al., } 2010 \\
\text { Rychli et al., } 2014\end{array}$ \\
\hline
\end{tabular}


utilizes fluorescently labeled probes (e.g., molecular beacon) to monitor the amplicons is developed in order to overcome this problem (Leone et al., 1998). A molecular beacon-based real time NASBA assay for the detection of $L$. monocytogenes in cooked ham and smoked salmon slices was first described by Nadal et al. (2007). Sequence from the mRNA transcript of hly gene was used as a target for this assay and the detection limit of this assay for L. monocytogenes was $400 \mathrm{CFU} / \mathrm{mL}$. This study also involved the use of a commercial NASBA kit, which was NucliSens ${ }^{\circledR}$ Basic Kit (bioMérieux) for the detection of L. monocytogenes.

DNA microarrays, which were initially being applied for the study of gene expression, could be used for the investigation of microbial evolution and epidemiology as well as for the detection of foodborne pathogens (Gasanov et al., 2005; Severgnini et al., 2011). DNA microarrays comprise multiple specific oligonucleotide probes (with sequence length ranges from 25 to $80 \mathrm{bp}$ ) or PCR probes which are coated on to glass slides or chips. The target nucleic acid which can be either DNA, mRNA or cDNA is labeled with fluorescent dye and then applied to the DNA microarray. The target nucleic acid will bind to its corresponding oligonucleotide probe and the hybridization is detected by production of fluorescent signal from probe-sample complex. DNA microarrays are capable of detecting multiple foodborne pathogens simultaneously and thus suitable for high-throughput analysis (De Boer and López, 2012; Law et al., 2015). An oligonucleotide DNA microarray assay that can simultaneously detect and discriminate six Listeria sp. including L. monocytogenes, L. ivanovii, L. innocua, L. seeligeri, L. grayi, and L. welshimeri was performed by Volokhov et al. (2002). The microarray assay was based on iap, $h l y$, inlB, $p l c A, p l c B$, and $c l p E$ genes for the identification of Listeria species. Oligonucleotide DNA microarray was also used for the simultaneous detection of different foodborne bacterial pathogens which include L. monocytogenes, E. coli O157:H7, Salmonella enterica and C. jejuni in food samples (Suo et al., 2010). DNA microarrays provide high-throughput analysis but the shortcoming is that large amounts of target DNA or RNA are needed for these methods (Gasanov et al., 2005).

The majority of bacterial genome sequences available today have been generated using the Sanger chain termination sequencing chemistries. Despite being very instrumental in the rise of the field of genomics, it is time consuming as well as resource intensive (Sanger et al., 1977; Medini et al., 2008). The post-Sanger era sequencing technologies, the NGS technologies, have been developed since 2005 to permit extremely rapid highthroughput whole genome sequencing (WGS) hence providing a broader application of comparative genomics (Medini et al., 2008; Shendure and Ji, 2008; Letchumanan et al., 2015a). Due

TABLE 3 | Advantages and limitations of molecular methods for the detection and identification of $L$. monocytogenes.

\begin{tabular}{|c|c|c|c|}
\hline $\begin{array}{l}\text { Molecular } \\
\text { methods }\end{array}$ & Advantages & Limitations & Reference \\
\hline Simple PCR & $\begin{array}{l}\text { - High sensitivity and specificity } \\
\text { - Accurate and reliable results }\end{array}$ & $\begin{array}{l}\text { - Sensitivity may be affected by non-optimized protocols } \\
\text { and PCR inhibitors } \\
\text { - Requires DNA purification step }\end{array}$ & $\begin{array}{l}\text { Mandal et al., 2011; } \\
\text { Letchumanan et al., } \\
\text { 2014; Law et al., } 2015\end{array}$ \\
\hline Multiplex PCR & $\begin{array}{l}\text { - High sensitivity and specificity } \\
\text { - Enables simultaneous detection of multiple foodborne } \\
\text { pathogens }\end{array}$ & $\begin{array}{l}\text { - Sensitivity may affected by non-optimized protocols and } \\
\text { PCR inhibitors } \\
\text { - Primer design and other mPCR conditions (e.g., primer } \\
\text { concentration, PCR buffer concentration, and quantities } \\
\text { of DNA template) are important }\end{array}$ & $\begin{array}{l}\text { Markoulatos et al., } \\
\text { 2002; Mandal et al., } \\
\text { 2011; Law et al., } 2015\end{array}$ \\
\hline $\begin{array}{l}\text { Real-time/ } \\
\text { quantitative } \\
\text { PCR }\end{array}$ & $\begin{array}{l}\text { - Higher sensitivity and specificity than simple PCR } \\
\text { - More rapid than simple PCR and mPCR as } \\
\text { post-amplification products processing is not required } \\
\text { - Assay can be multiplexed } \\
\text { - Allows high-throughput analysis }\end{array}$ & $\begin{array}{l}\text { - Costly } \\
\text { - Sensitivity may affected by PCR inhibitors } \\
\text { - Trained personnel is needed }\end{array}$ & $\begin{array}{l}\text { Oravcová et al., 2005; } \\
\text { Mandal et al., 2011; } \\
\text { Letchumanan et al., } \\
\text { 2014; Law et al., } 2015\end{array}$ \\
\hline LAMP & $\begin{array}{l}\text { - Higher sensitivity and specificity than PCR } \\
\text { - Cost-effective } \\
\text { - Simple } \\
\text { - Operates without thermal cycling system }\end{array}$ & - Complicated primer design & $\begin{array}{l}\text { Letchumanan et al., } \\
\text { 2014; Zhao et al., } \\
\text { 2014; Law et al., } 2015\end{array}$ \\
\hline NASBA & $\begin{array}{l}\text { - Sensitive and specific } \\
\text { - Cost-effective } \\
\text { - Operates without thermal cycling system } \\
\text { - Enables the detection of viable bacteria }\end{array}$ & $\begin{array}{l}\text { - Requires viable bacteria } \\
\text { - Might not be easy to handle RNA }\end{array}$ & $\begin{array}{l}\text { Lauri and Mariani, } \\
\text { 2009; Zhao et al., } \\
\text { 2014; Law et al., } 2015\end{array}$ \\
\hline DNA microarray & $\begin{array}{l}\text { - High sensitivity and specificity } \\
\text { - Enables simultaneous detection of multiple foodborne } \\
\text { pathogens } \\
\text { - Allows high-throughput analysis }\end{array}$ & $\begin{array}{l}\text { - Costly } \\
\text { - Trained personnel is needed } \\
\text { - Requires large amount of target DNA or RNA }\end{array}$ & $\begin{array}{l}\text { Gasanov et al., 2005; } \\
\text { Lauri and Mariani, } \\
\text { 2009; Law et al., } 2015\end{array}$ \\
\hline NGS & $\begin{array}{l}\text { - High sensitivity and specificity } \\
\text { - Enables simultaneous detection of multiple foodborne } \\
\text { pathogens } \\
\text { - Allows high-throughput analysis } \\
\text { - Enable the analysis of whole genome of the pathogens }\end{array}$ & $\begin{array}{l}\text { - Costly } \\
\text { - Trained personnel is needed } \\
\text { - Requires Bioinformatics skills for analysis and } \\
\text { interpretation } \\
\text { - Computationally intensive }\end{array}$ & $\begin{array}{l}\text { Sabat et al., 2013; } \\
\text { Fournier et al., } 2014\end{array}$ \\
\hline
\end{tabular}


to rapid decreasing costs for sequencers and reagents, a bacterial genome sequence can be obtained within a few days for less than US\$500 (Didelot et al., 2012), and more than 36,000 bacterial genome sequences are available in public databases (Reddy et al., 2015). Other than serving as a detection tool, WGS is also a feasible tool for retrospective epidemiological analyses and is frequently used for the latter purpose. Genome sequencing of several L. monocytogenes strains have revealed serotype- and strain-specific characteristics of L. monocytogenes (Orsi et al., 2008; Fretz et al., 2010; Gilmour et al., 2010) and provided novel insights into the genomic causes underlying pathogenicity and survival in food and food processing settings (Buchrieser and Glaser, 2011).

A listeriosis outbreak in Oklahoma, USA in the year 1988 was linked to the consumption of turkey franks contaminated with $L$. monocytogenes produced in a food processing facility in Texas, USA (Centers for Disease Control, and Prevention [CDC], 1989). In 2000, 11 states in the US faced listeriosis outbreak affecting 29 individuals including four fatalities, and it was linked to consumption of deli turkey meat produced in the same facility (Stone and Shoenberger, 2001; Olsen et al., 2005). Using NGS, Orsi et al. (2008) revealed that the human listeriosis outbreak in 2000 in the USA was caused by a L. monocytogenes strain that persisted in that food processing plant for over 12 years in which the same strain has also been responsible for a sporadic case in 1988.

In $2008, L$. monocytogenes serotype $1 / 2$ a caused an outbreak of listeriosis associated with ready to eat meat products in Canada, resulting in 22 deaths and at least 57 illnesses (Gilmour et al., 2010). The authors reported the first real-time application of WGS during an active listeriosis outbreak investigation using the high-throughput to characterize two outbreak-associated isolates of L. monocytogenes. In 2009 and 2010, another large listeriosis outbreak occurred in Austria, Germany, and the Czech Republic due to intake of a traditional Austrian cheese called "Quargel," an acid curd cheese with a red smear made from skimmed pasteurized milk (Fretz et al., 2010). Molecular typing via PFGE revealed that two different L. monocytogenes strains, both serotype 1/2a (Pichler et al., 2011). From June 2009 to January 2010 Quargel outbreak clone 1 (QOC1) was the culprit in 14 cases, including five with a lethal outcome (Fretz et al., 2010). Whereas between December 2009 and February 2010, Quargel outbreak clone 2 (QOC2) accounted for 20 cases, which resulted in three deaths (Fretz et al., 2010). Rychli et al. (2014) sequenced and analyzed the genomes of both outbreak strains in order to retrospectively investigate the extent of genetic diversity between the two strains. WGS analysis revealed that these two strains have distinct in vitro virulence potential despite originating from similar serovar (Rychli et al., 2014).

The development of benchtop sequencers using NGS technology such as 454 or GS FLX ${ }^{\mathrm{TM}}$ (Roche), MiSeq (Illumina) and Ion Torrent Personal Genome Sequencer (PGM; Life Technologies) will enable bacterial WGS even in small research and clinical laboratories (Didelot et al., 2012). WGS has already been actively used for the characterization of bacterial isolates in several large outbreaks in the world (Gilmour et al.,
2010; Reuter et al., 2013) and also being used as a tool for retrospective epidemiological analyses (Orsi et al., 2008; Rychli et al., 2014). In the near future this technology is likely to substitute currently used typing methodologies due to its ultimate resolution and sensitivity (Sabat et al., 2013). However, NGS also has its limitation. Until now, it is still too laborious and time-consuming to obtain useful data for routine surveillance (Fournier et al., 2014). Library preparation and sequencing protocol requires adept and skillful technician; however, this limitations are likely to be overcome due to higher level of automation which will lead to a more streamline processed. Bioinformatics analysis and interpretation, as well as computational hardware are also another challenges to be solved especially by small laboratories (Fournier et al., 2014). In addition, a fundamentally unsolved question is how the sequences should be examined for epidemiological characterization (Sabat et al., 2013). More examples of studies that involved the application of molecular methods for the detection and identification of L. monocytogenes in food samples are listed in Table 2.

There are many advantages of using molecular methods for the detection and identification of L. monocytogenes. For instance, the main advantages of molecular detection methods are due to their high sensitivity and specificity. Nonetheless, limitations can be found in these methods such as some molecular methods can be costly, complex and require trained personnel. The advantages and limitations of molecular methods are summarized and listed in Table 3.

\section{CONCLUSION}

Early detection of $L$. monocytogenes contaminated food is crucial as it can prevent the outbreaks of foodborne illness. Till date, the culture reference methods mentioned in this review are still applicable and being used in many studies. Simple PCR and mPCR have been used routinely for rapid, sensitive, and specific screening as well as confirmation of L. monocytogenes. The introduction of LAMP and NASBA allow accurate and cost-effective screening of L. monocytogenes. For large number of samples, high-throughput assays such as qPCR and DNA microarray are often used for the detection of L. monocytogenes. Cultural and molecular techniques are continuously being developed and improved in order to provide higher sensitivity and specificity of L. monocytogenes detection. The advancements of molecular methods allow the rapid detection of L. monocytogenes in food samples with high sensitivity and specificity whilst substituting the lengthy and laborious conventional detection methods. Molecular methods have provide many advantages, nonetheless, there are still some limitations in these methods such as the need to use highly advance technology that are costly compared to conventional methods. The combined use of two or more detection methods is also possible and may improve the accuracy of detecting L. monocytogenes. Still, there are great potential for the development and application of new techniques for foodborne pathogens detection and analysis. 


\section{ACKNOWLEDGMENTS}

This work was supported by a University of Malaya for High Impact Research Grant (UM-MOHE HIR Nature Microbiome

\section{REFERENCES}

Agersborg, A., Dahl, R., and Martinez, I. (1997). Sample preparation and DNA extraction procedures for polymerae chain reaction identification of Listeria monocytogenes in seafoods. Int. J. Food Microbiol. 35, 275-280. doi: 10.1016/S0168-1605(97)01245-2

Ajay Kumar, V. J., Latha, C., Sunil, B., and Dhanya, V. R. (2014). Comparison of different cultural techniques in isolation of Listeria monocytogenes from various samples. J. Foodborne Zoonotic Dis. 2, 10-14.

Alessandria, V., Rantsiou, K., Dolci, P., and Cocolin, L. (2010). Molecular methods to asses Listeria monocytogenes route of contamination in a dairy processing plant. Int. J. Food Microbiol. 141, S156-S162. doi: 10.1016/j.ijfoodmicro.2010.02.001

Almeida, P. F., and Almeida, R. C. C. (2000). A PCR protocol using inl gene as a target for specific detection of Listeria monocytogenes. Food Control 11, 97-101. doi: 10.1016/S0956-7135(99)00067-5

Amagliani, G., Brandi, G., Omiccioli, E., Casiere, A., Bruce, I. J., and Magnani, M. (2004). Direct detection of Listeria monocytogenes from milk by magnetic based DNA isolation and PCR. Food Microbiol. 21, 597-603. doi: 10.1016/j.fm.2003.10.008

Andritsos, N. D., Mataragas, M., Paramithiotis, S., and Drosinos, E. H. (2013). Quantifying Listeria monocytogenes prevalence and concentration in minced pork meat and estimating performance of three culture media from presence/absence microbiological testing using a deterministic and stochastic approach. Food Microbiol. 36, 395-405. doi: 10.1016/j.fm.2013. 06.020

Aragon-Alegro, L. C., Aragon, D. C., Martinez, E. Z., Landgraf, M., De Melo Franco, B. D. G., and Destro, M. T. (2008). Performance of a chromogenic medium for the isolation of Listeria monocytogenes in food. Food Control 19, 483-486. doi: 10.1016/j.foodcont.2007.05.013

Aznar, R., and Alarcón, B. (2003). PCR detection of Listeria monocytogenes: a study of multiple factors affecting sensitivity. J. Appl. Microbiol. 95, 958-966. doi: 10.1046/j.1365-2672.2003.02066.x

Bang, J., Beuchat, L. R., Song, H., Gu, M. B., Chang, H. I., Kim, H. S., et al. (2013). Development of random genomic DNA microarray for the detection, and identification of Listeria monocytogenes in milk. Int. J. Food Microbiol. 161, 134-141. doi: 10.1016/j.ijfoodmicro.2012.11.023

Barbau-Piednoir, E., Botteldoorn, N., Yde, M., Mahillon, J., and Roosens, N. H. (2013). Development and validation of qualitative $S Y B R{ }^{\circledR}$ Green real-time PCR for detection and discrimination of Listeria spp. and Listeria monocytogenes. Appl. Microbiol. Biotechnol. 97, 4021-4037. doi: 10.1007/s00253-012$4477-2$

Becker, B., Jordan, S., and Holzapfel, W. H. (2005). Rapid and specific detection of Listeria monocytogenes in smoked salmon with BAX ${ }^{\circledR}$-PCR. Food Control 16, 717-721. doi: 10.1016/j.foodcont.2004.06.009

Berrada, H., Soriano, J. M., Picó, Y., and Mañes, J. (2006). Quantification of Listeria monocytogenes in salads by real time quantitative PCR. Int. J. Food Microbiol. 107, 202-206. doi: 10.1016/j.ijfoodmicro.2005.07.006

Beumer, R. R., and Hazeleger, W. C. (2003). Listeria monocytogenes: diagnostic problems. FEMS Immunol. Med. Microbiol. 35, 191-197. doi: 10.1016/S09288244(02)00444-3

Blais, B. W., Turner, G., Sooknanan, R., and Malek, L. T. (1997). A nucleic acid sequence-based amplification system for detection of Listeria monocytogenes hlyA sequences. Appl. Environ. Microbiol. 63, 310-313. doi: 10.1007/BF00158944

Buchrieser, C., and Glaser, P. (2011). Genomics of Listeria monocytogenes and Other Members of the Genus Listeria. Genomes of Foodborne and Waterborne Pathogens. Washington DC: ASM Press, 125-145.

Burbano, E., Sierra, S., Torres, K., Mercado, M., Carrascal, A., and Poutou, R. (2006). Rapid DNA extraction and PCR validation for direct detection of Listeria monocytogenes in raw milk. Rev. MVZ Cordoba 11, 715-724.
Grant No. H-50001-A000027 and No. A000001-50001) awarded to CK-G and External Industry Grants from Biotek Abadi Sdn Bhd (vote no. GBA-808138 and GBA-808813) awarded to LL-H.

Bush, S. V., and Donnelly, C. W. (1992). Development of a repair-enrichment broth for resuscitation of heat-injured Listeria monocytogenes and Listeria innocua. Appl. Environ. Microbiol. 58, 14-20.

Centers for Disease Control, and Prevention [CDC] (1989). Epidemiological (Notes) and reports listeriosis associated with consumption of turkey franks. Morbidity Mortailty Wkly. Rep. 38, 267-268.

Chen, J., Tang, J., Liu, J., Cai, Z., and Bai, X. (2012). Development and evaluation of a multiplex PCR for simultaneous detection of five foodborne pathogens. J. Appl. Microbiol. 112, 823-830. doi: 10.1111/j.1365-2672.2012.05240.x

Cho, A. R., Dong, H. J., Seo, K. H., and Cho, S. (2014). Development of a loopmediated isothermal amplification assay for detecting Listeria monocytogenes prfA in milk. Food Sci. Biotechnol. 23, 467-474. doi: 10.1007/s10068-0140064-x

Churchill, R. L. T., Lee, H., and Hall, J. C. (2006). Detection of Listeria monocytogenes and the toxin listeriolysin O in food. J. Microbiol. Methods 64, 141-170. doi: 10.1016/j.mimet.2005.10.007

Cook, N. (2003). The use of NASBA for the detection of microbial pathogens in food and environmental samples. J. Microbiol. Methods 53, 165-174. doi: 10.1016/S0167-7012(03)00022-8

Cooray, K. J., Nishibori, T., Xiong, H., Matsuyama, T., Fujita, M., and Mitsuyama, M. (1994). Detection of multiple virulence associated-genes of Listeria monocytogenes by PCR in artificially contaminated milk samples. Appl. Environ. Microbiol. 60, 3023-3026.

Cossart, P., Vicente, M. F., Mengaud, J., Baquero, F., Perez-Diaz, J. C., and Berche, P. (1989). Listeriolysin O is essential for virulence of Listeria monocytogenes: direct evidence obtained by gene complementation. Infect. Immun. 57, 3629-3636.

Curtis, G. D. W., Mitchell, R. G., King, A. F., and Griffin, E. J. (1989). A selective differential medium for the isolation of Listeria monocytogenes. Lett. Appl. Microbiol. 8, 95-98. doi: 10.1111/j.1472-765X.1989.tb00231.x

Da Silva, E. P., and De Martinis, E. C. P. (2013). Current knowledge and perspective on biofilm formation: the case of Listeria monocytogenes. Appl. Microbiol. Biotechnol. 97, 957-968. doi: 10.1007/s00253-012-4611-1

De Boer, S. H., and López, M. M. (2012). New grower-friendly methodsfor plant pathogen monitoring. Annu. Rev. Phytopathol. 50, 197-218. doi: 10.1146/annurev-phyto-081211-172942

Deneer, H. G., and Boychuk, I. (1991). Species-specific detection of Listeria monocytogenes by DNA amplification. Appl. Environ. Microbiol. 57, 606-609.

De Oliveira, M. A., Ribeiro, E. G. A., Bergamini, A. M. M., and De Martinis, E. C. P. (2010). Quantification of Listeria monocytogenes in minimally processed leafy vegetables using a combined method based on enrichment and $16 \mathrm{~S}$ rRNA real-time PCR. Food Microbiol. 27, 19-23. doi: 10.1016/j.fm.2009. 07.003

Didelot, X., Bowden, R., Wilson, D. J., Peto, T. E., and Crook, D. W. (2012). Transforming clinical microbiology with bacterial genome sequencing. Nat. Rev. Genet. 13, 601-612. doi: 10.1038/nrg3226

Donnelly, C. W., and Baigent, G. J. (1986). Method for flow cytometric detection of Listeria monocytogenes in milk. Appl. Environ. Microbiol. 52, 689-695.

Doumith, M., Buchrieser, C., Glaser, P., Jacquet, C., and Martin, P. (2004). Differentiation of the major Listeria monocytogenes serovars by multiplex PCR J. Clin. Microbiol. 42, 3819-3822. doi: 10.1128/JCM.42.8.3819-3822.2004

Dwivedi, H. P., and Jaykus, L. A. (2011). Detection of pathogens in foods: the current state-of-the-art and future directions. Crit. Rev. Microbiol. 37, 40-63. doi: 10.3109/1040841X.2010.506430

El Marrakchi, A., Boum'handi, N., and Hamama, A. (2005). Performance of a new chromogenic plating medium for the isolation of Listeria monocytogenes from marine environments. Lett. Appl. Mircrobiol. 40, 87-91. doi: 10.1111/j.1472765X.2004.01651.x

Erol, I., and Ayaz, N. D. (2011). Serotype distribution of Listeria monocytogenes isolated from Turkey meat by multiplex PCR in Turkey. J. Food Saf. 31, 149-153. doi: 10.1111/j.1745-4565.2010.00278.x 
Farber, J. M., Ross, W. H., and Harwig, J. (1996). Health risk assessment of Listeria monocytogenes in Canada. Int. J. Food Microbiol. 30, 145-156. doi: 10.1016/0168-1605(96)01107-5

Fournier, P. E., Dubourg, G., and Raoult, D. (2014). Clinical detection and characterization of bacterial pathogens in the genomics era. Genome Med. 6:114. doi: 10.1186/s13073-014-0114-2

Fraser, J. A., and Sperber, W. H. (1988). Rapid detection of Listeria spp. in food and environmental samples by esculin hydrolysis. J. Food Prot. 51, 762-765.

Fretz, R., Sagel, U., Ruppitsch, W., Pietzka, A., Stoger, A., Huhulescu, S., et al. (2010). Listeriosis outbreak caused by acid curd cheese Quargel. Austria and Germany 2009. Euro. Surveill. 15:pii:19477.

Fricker, M., Messelhäußer, U., Busch, U., Scherer, S., and Ehling-Schulz, M. (2007). Diagnostic real-time PCR assays for the detection of emetic Bacillus cereus strains in foods and recent food-borne outbreaks. Appl. Environ. Microbiol. 73 1892-1898. doi: 10.1128/AEM.02219-06

Garrido, A., Chapela, M. J., Román, B., Fajardo, P., Vieites, J. M., and Cabado, A. G. (2013). In-house validation of a multiplex real-time PCR method for simultaneous detection of Salmonella spp., Escherichia coli O157:H7 and Listeria monocytogenes. Int. J. Food Microbiol. 164, 92-98. doi: 10.1016/j.ijfoodmicro.2013.03.024

Gasanov, U., Hughes, D., and Mansbro, P. M. (2005). Methods for the isolation and identification of Listeria spp. and Listeria monocytogenes: a review. FEMS Microbiol. Rev. 29, 851-875. doi: 10.1016/j.femsre.2004.12.002

Gattuso, A., Gianfranceschi, M. V., Sonnessa, M., Delibato, E., Marchesan, M. Hernandez, M., et al. (2014). Optimization of real time PCR based method for the detection of Listeria monocytogenes in pork meat. Int. J. Food Microbiol. 184, 106-108. doi: 10.1016/j.ijfoodmicro.2014.04.015

Germini, A., Masola, A., Carnevali, P., and Marchelli, R. (2009). Simultaneous detection of Escherichia coli O157:H7, Salmonella spp., and Listeria monocytogenes by multiplex PCR. Food Control 20, 733-738. doi 10.1016/j.foodcont.2008.09.010

Gianfranceschi, M. V., Rodriguez-Lazaro, D., Hernandez, M., González-García, P., Comin, D., Gattuso, A., et al. (2014). European validation of a real-time PCRbased method for detection of Listeria monocytogenes in soft cheese. Int. J. Food Microbiol. 184, 128-133. doi: 10.1016/j.ijfoodmicro.2013.12.021

Gilbert, C., O'Leary, A., Winters, D., and Slavik, M. (2003). Development of a multiplex PCR assay for the specific detection of Salmonella, Campylobacter jejuni, Escherichia coli O157:H7, and Listeria monocytogenes. J. Rapid Methods Autom. Microbiol. 11, 61-74. doi: 10.1111/j.1745-4581.2003.tb 00409.x

Gilmour, M. W., Graham, M., Van Domselaar, G., Tyler, S., Kent, H., TroutYakel, K. M., et al. (2010). High-throughput genome sequencing of two Listeria monocytogenes clinical isolates during a large foodborne outbreak. BMC Genomics 11:120. doi: 10.1186/1471-2164-11-120

Gilot, P., and Content, J. (2002). Specific identification of Listeria welshimeri and Listeria monocytogenes by PCR assays targeting a gene encoding a fibronectinbinding protein. J. Clin. Microbiol. 40, 698-703. doi: 10.1128/JCM.40.2.698703.2002

Goh, S. G., Kuan, C. H., Loo, Y. Y., Chang, W. S., Lye, Y. L., Soopna, P., et al. (2012). Listeria monocytogenes in retailed raw chicken meat in Malaysia. Poult. Sci. 91, 2686-2690. doi: 10.3382/ps.2012-02349

Golsteyn-Thomas, E. J., King, R. K., Burchak, J., and Gannon, V. P. J. (1990). Sensitive and specific detection of Listeria monocytogenes in milk and ground beef with the polymerase chain reaction. Appl. Environ. Microbiol. 57, 25762580 .

Graham, T. A., Golsteyn-Thomas, E. J., Gannon, V. P. J., and Thomas, J. E. (1996). Genus- and species-specific detection of Listeria monocytogenes using polymerase chain reaction assays targeting the $16 \mathrm{~S} / 23 \mathrm{~S}$ intergenic spacer region of the rRNA operon. Can. J. Microbiol. 42, 1155-1162. doi: 10.1139/ m96-147

Graham, T. A., Golsteyn-Thomas, E. J., Thomas, J. E., and Gannon, V. P. J. (1997). Inter- and intraspecies comparison of the 16S-23S rRNA operon intergenic spacer regions of six Listeria spp. Int. J. Syst. Bacteriol. 47, 863-869. doi: 10.1099/00207713-47-3-863

Groves, R. D., and Welshimer, H. J. (1977). Separation of pathogenic from apathogenic Listeria monocytogenes by three in vitro reactions. J. Clin. Microbiol. 5, 559-563.
Gudbjörnsdóttir, B., Suihko, M. L., Gustavsson, P., Thorkelsson, G., Salo, S. Sjöberg, A. M., et al. (2004). The incidence of Listeria monocytogenes in meat, poultry and seafood plants in the Nordic countries. Food Microbiol. 21, 217-225. doi: 10.1016/S0740-0020(03)00012-1

Hage, E., Mpamugo, O., Ohai, C., Sapkota, S., Swift, C., Wooldridge, D., et al. (2014). Identification of six Listeria species by real-time PCR assay. Lett. Appl. Microbiol. 58, 535-540. doi: 10.1111/lam.12223

Hamdi, T. H., Naïm, M., Martin, P., and Jacquet, C. (2007). Identification and molecular characterization of Listeria monocytogenes isolated in raw milk in the region of Algiers (Algeria). Int. J. Food Microbiol. 116, 190-193. doi 10.1016/j.ijfoodmicro.2006.12.038

Hegde, V., Leon-Velarde, C. G., Stam, C. M., Jaykus, L. A., and Odumeru, J. A. (2007). Evaluation of BBL CHROMagar Listeria agar for the isolation and identification of Listeria monocytogenes from food and environmental samples. J. Microbiol. Methods 68, 82-87. doi: 10.1016/j.mimet.2006.06.011

Hein, I., Klein, D., Lehner, A., Bubert, A., Brandl, E., and Wagner, M. (2001). Detection and quantification of the iap gene of Listeria monocytogenes and Listeria innocua by a new real-time quantitative PCR assay. Res. Microbiol. 152, 37-46. doi: 10.1016/S0923-2508(00)01166-9

Hitchins, A. D., and Jinneman, K. (2013). Bacteriological Analytical Manual (BAM) Chapter 10: Detection and Enumeration of Listeria monocytogenes in Foods. Available at: http://www.fda.gov/Food/FoodScienceResearch/ LaboratoryMethods/ucm071400.htm [accessed May 16, 2015].

Ingianni, A., Floris, M., Palomba, P., Madeddu, M. A., Quartuccio, M., and Pompei, R. (2001). Rapid detection of Listeria monocytogenes in foods, by a combination of PCR and DNA probe. Mol. Cell. Probes 15, 275-280. doi: 10.1006/mcpr.2001.0372

International Commission on Microbiological Specifications for Foods [ICMSF] (1996). Microorganisms in Foods 5 - Characteristics of Microbial Pathogens. London: Blackie Academic \& Professional, 148.

ISO (2004a). EN ISO 11290-1:1996/Amd 1:2004 Microbiology of Food and Animal Feeding Stuffs - Horizontal Method for the Detection and Enumeration of Listeria monocytogenes - Detection Method, Part I. Geneva: International Organization for Standardization.

ISO (2004b). EN ISO 11290-2:1998/Amd 1:2004 Microbiology of Food and Animal Feeding Stuffs - Horizontal Method for the Detection and Enumeration of Listeria monocytogenes - Enumeration Method, Part II. Geneva: International Organization for Standardization.

Jadhav, S., Bhave, M., and Palombo, E. A. (2012). Methods used for the detection and subtyping of Listeria monocytogenes. J. Microbiol. Methods 88, 327-341. doi: 10.1016/j.mimet.2012.01.002

Jamali, H., Chai, L. C., and Thong, K. L. (2013). Detection and isolation of Listeria spp. and Listeria monocytogenes in ready-to-eat foods with various selective culture media. Food Control 32, 19-24. doi: 10.1016/j.foodcont.2012. 11.033

Janzten, M. M., Navas, J., Corujo, A., Moreno, R., López, V., and Martínez-Suárez, J. V. (2006). Review. Specific detection of Listeria monocytogenes in foods using commercial methods: from chromogenic media to real-time PCR. Span. J. Agric. Res. 4, 235-247. doi: 10.5424/sjar/2006043-198

Jemmi, T., and Stephan, R. (2006). Listeria monocytogenes: food-borne pathogen and hygiene indicator. Rev. Sci. Tech. 25, 571-580.

Jeyaletchumi, P., Tunung, R., Margaret, S. P., Son, P., Farinazleen, M. G., and Cheah, Y. K. (2010a). Detection of Listeria monocytogenes in foods. Int. Food Res. J. 17, 1-11.

Jeyaletchumi, P., Tunung, R., Margaret, S. P., Son, R., Ghazali, F. M., Cheah, Y. K., et al. (2010b). Quantification of Listeria monocytogenes in salad vegetables by MPN-PCR. Int. Food Res. J. 17, 281-286. doi: 10.1155/2014/608296

Jofré, A., Martin, B., Garriga, M., Hugas, M., Pla, M., and Rodríguez-Lázaro, D. (2005). Simultaneous detection of Listeria monocytogenes and Salmonella by multiplex PCR in cooked ham. Food Microbiol. 22, 109-115. doi: 10.1016/j.fm.2004.04.009

Johnson, W. M., Tyler, S. D., Ewan, E. P., Ashton, F. E., Wang, G., and Rozee, K. R. (1992). Detection of genes coding for listeriolysin and Listeria monocytogenes antigen A (lmaA) in Listeria spp. by the polymerase chain reaction. Microb. Pathog. 12, 79-86. doi: 10.1016/0882-4010(92)90068-Y

Jung, Y. S., Frank, J. F., Brackett, R. E., and Chen, J. (2003). Polymerase chain reaction detection of Listeria monocytogenes in frankfurters using 
oligonucleotide primers targeting the genes encoding internalin AB. J. Food Prot. 66, 237-241.

Kathariou, S., Metz, P., Hof, H., and Goebel, W. (1987). Tn916-induced mutations in the hemolysin determinant affecting virulence of Listeria monocytogenes. J. Bacteriol. 169, 1291-1297.

Khan, J. A., Rathore, R. S., Khan, S., and Ahmad, I. (2013). In vitro detection of pathogenic Listeria monocytogenes from food sources by conventional, molecular and cell culture method. Braz. J. Microbiol. 44, 751-758. doi: $10.1590 /$ S1517-83822013000300013

Kim, H. J., and Cho, J. C. (2010). Simple and rapid detection of Listeria monocytogenes in fruit juice by real-time PCR without enrichment culture. Food Control 21, 1419-1423. doi: 10.1016/j.foodcont.2010.04.006

Kraiss, J. B. R. K. (2008). Listeria Regulations in the fda and usda: Implications for Dual-Jurisdiction facilitites. Food regulation in the United States, 1-18. Available at: http://www.iflr.msu.edu/uploads/files/Student\%20Papers/Janet \%20B.\%20Rowat\%20KraissListeriaRegulationsFDAandUSDA.pdf [accessed September 23, 2015].

Kramarenko, T., Roasto, M., Meremäe, K., Kuningas, M., Põltsama, P., and Elias, T. (2013). Listeria monocytogenes prevalence and serotype diversity in various foods. Food Control 30, 24-29. doi: 10.1016/j.foodcont.2012. 06.047

Kumar, T. D. K., Murali, H. S., and Batra, H. V. (2009). Simultaneous detection of pathogenic B. cereus, S. aureus and L. monocytogenes by multiplex PCR. Indian J. Microbiol. 49, 283-289. doi: 10.1007/s12088-009-0032-y

Lambertz, S. T., Nilsson, C., Brådenmark, A., Sylvén, S., Johansson, A., Jansson, L. M., et al. (2012). Prevalence and level of Listeria monocytogenes in ready-to-eat foods in Sweden 2010. Int. J. Food Microbiol. 160, 24-31. doi: 10.1016/j.ijfoodmicro.2012.09.010

Lauri, A., and Mariani, P. O. (2009). Potentials and limitations of molecular diagnostic methods in food safety. Genes Nutr. 4, 1-12. doi: 10.1007/s12263008-0106-1

Law, J. W. F., Ab Mutalib, N. S., Chan, K. G., and Lee, L. H. (2015). Rapid methods for the detection of foodborne bacterial pathogens: principles, applications, advantages and limitations. Front. Microbiol. 5:770. doi: 10.3389/fmicb.2014.00770

Lawrence, L. M., and Gilmour, A. (1994). Incidence of Listeria spp. and Listeria monocytogenes in a poultry processing environment and in poultry products and their rapid confirmation by multiplex PCR. Appl. Eviron. Microbiol. 60, $4600-4604$.

Lee, N., Kwon, K. Y., Oh, S. K., Chang, H. J., Chun, H. S., and Choi, S. W. (2014). A multiplex PCR assay for simultaneous detection of Escherichia coli O157:H7, Bacillus cereus, Vibrio parahaemolyticus, Salmonella spp., Listeria monocytogenes, and Staphylococcus aureus in Korean ready-to-eat food. Foodborne Pathog. Dis. 11, 574-580. doi: 10.1089/fpd.2013.1638

Leone, G., van Schijndel, H., van Gemen, B., Kramer, F. R., and Schoen, C. D. (1998). Molecular beacon probes combined with amplification by NASBA enable homogenous, real-time detection of RNA. Nucleic Acids Res. 26, 21502155. doi: $10.1093 / \mathrm{nar} / 26.9 .2150$

Letchumanan, V., Chan, K. G., and Lee, L. H. (2014). Vibrio parahaemolyticus: a review on the pathogenesis, prevalence, and advance molecular identification techniques. Front. Microbiol. 5:705. doi: 10.3389/fmicb.2014. 00705

Letchumanan, V., Chan, K. G., and Lee, L. H. (2015a). An insight of traditional plasmid curing in Vibrio species. Front. Microbiol. 6:735. doi: 10.3389/fmicb.2015.00735

Letchumanan, V., Yin, W. F., Lee, L. H., and Chan, K. G. (2015b). Prevalence and antimicrobial susceptibility of Vibrio parahaemolyticus isolated from retail shrimps in Malaysia. Front. Microbiol. 6:33. doi: 10.3389/fmicb.2015. 00033

Levin, R. E. (2003). Application of the polymerase chain reaction for detection of Listeria monocytogenes in foods: a review of methodology. Food Biotechnol. 17, 99-116. doi: 10.1081/FBT-120023074

Liming, S. H., Zhang, Y., Meng, J., and Bhagwat, A. A. (2004). Detection of Listeria monocytogenes in fresh produce using molecular beacon-realtime PCR technology. J. Food Sci. 69, M240-M245. doi: 10.1111/j.17503841.2004.tb18020.x
Liu, D. (2006). Identification, subtyping and virulence determination of Listeria monocytogenes, an important foodborne pathogen. J. Med. Microbiol. 55, 645659. doi: 10.1099/jmm.0.46495-0

Liu, D., Lawrence, M. L., Austin, F. W., and Ainsworth, A. J. (2007). A multiplex PCR for species- and virulence-specific determination of Listeria monocytogenes. J. Microbiol. Methods 71, 133-140. doi: 10.1016/j.mimet.2007.08.007

Liu, H., Lu, L., Pan, Y., Sun, X., Hwang, C. A., Zhao, Y., et al. (2015). Rapid detection and differentiation of Listeria monocytogenes and Listeria species in deli meats by a new multiplex PCR method. Food Control 52, 78-84. doi: 10.1016/j.foodcont.2014.12.017

Liu, P., Mizue, H., Fujihara, K., Kobayashi, H., Kamikado, H., Tanaka, T., et al. (2012). A new rapid real-time PCR method for detection of Listeria monocytogenes targeting the hlyA gene. Food Sci. Technol. Res. 18, 47-57. doi: $10.3136 /$ fstr. 18.47

Lovett, J., Francis, D. W., and Hunt, J. M. (1987). Listeria monocytogenes in raw milk: detection, incidence, and pathogenicity. J. Food Prot. 50, 188-192. doi: 10.1128/AEM.00219-13

Magalhães, R., Mena, C., Ferreira, V., Almeida, G., Silva, J., and Teixeira, P. (2014). "Traditional methods for isolation of Listeria monocytogenes," in Listeria monocytogenes: Methods and Protocols, eds K. Jordan, E. M. Fox, and M. Wagner (New York, NY: Springer Science), 15-30.

Mandal, P. K., Biswas, A. K., Choi, K., and Pal, U. K. (2011). Methods for rapid detection of foodborne pathogens: an overview. Am. J. Food Technol. 6, 87-102. doi: 10.3923/ajft.2011.87.102

Markoulatos, P., Siafakas, N., and Moncany, M. (2002). Multiplex polymerase chain reaction: a practical approach. J. Clin. Lab. Anal. 16, 47-51. doi: $10.1002 /$ jcla. 2058

Martín, B., Jofré, A., Garriga, M., Hugas, M., and Aymerich, T. (2004). Quantification of Listeria monocytogenes in fermented sausages by MPNPCR method. Lett. Appl. Microbiol. 39, 290-295. doi: 10.1111/j.1472765X.2004.01580.X

Medini, D., Serruto, D., Parkhill, J., Relman, D. A., Donati, C., Moxon, R., et al. (2008). Microbiology in the post-genomic era. Nat. Rev. Microbiol. 6, 419-430. doi: 10.1038/nrmicro1901

Mena, C., Almeida, G., Carneiro, L., Teixeira, P., Hogg, T., and Gibbs, P. A. (2004). Incidence of Listeria monocytogenes in different food products commercialized in Portugal. Food Microbiol. 21, 213-216. doi: 10.1016/S0740-0020(03) 00057-1

Moriishi, K., Terao, M., Koura, M., and Inoue, S. (1998). Sequence analysis of the actA gene of Listeria monocytogenes isolated from human. Microbiol. Immunol. 42, 129-132. doi: 10.1111/j.1348-0421.1998.tb02261.x

Murphy, R. Y., Duncan, L. K., Driscoll, K. H., Beard, B. L., Berrang, M. B., and Marcy, J. A. (2003). Determination of thermal lethality of Listeria monocytogenes in fully cooked chicken breast fillets and strips during postcook in-package pasteurization. J. Food. Prot. 66, 578-583.

Nadal, A., Coll, A., Cook, N., and Pla, M. (2007). A molecular beacon-based real time NASBA assay for detection of Listeria monocytogenes in food products: role of target mRNA secondary structure on NASBA design. J. Microbiol. Methods 68, 623-632. doi: 10.1016/j.mimet.2006.11.011

Navas, J., Ortiz, S., Lopez, P., Jantzen, M. M., Lopez, V., and Martinez-Suarez, J. V. (2006). Evaluation of effects of primary and secondary enrichment for the detection of Listeria monocytogenes by real-time PCR in retail ground chicken meat. Foodborne Pathog. Dis. 3, 347-354. doi: 10.1089/fpd.2006.3.347

O'Grady, J., Sedano-Balbás, S., Maher, M., Smith, T., and Barry, T. (2008). Rapid real-time PCR detection of Listeria monocytogenes in enriched food samples based on the ssrA gene, a novel diagnostic target. Food Microbiol. 25, 75-84. doi: 10.1016/j.fm.2007.07.007

Olsen, S. J., Patrick, M., Hunter, S. B., Reddy, V., Kornstein, L., MacKenzie, W. R., et al. (2005). Multistate outbreak of Listeria monocytogenes infection linked to delicatessen turkey meat. Clin. Infect. Dis. 40, 962-967. doi: 10.1086/ 428575

Oravcová, K., Kaclíková, E., Krascsenicsová, K., Pangallo, D., Brežná, B., Siekel, P., et al. (2005). Detection and quantification of Listeria monocytogenes by 5 '-nuclease polymerase chain reaction targeting the actA gene. Lett. Appl. Microbiol. 42, 15-18. doi: 10.1111/j.1472-765X.2005.01793.x 
Orsi, R. H., Borowsky, M. L., Lauer, P., Young, S. K., Nusbaum, C., Galagan, J. E., et al. (2008). Short-term genome evolution of Listeria monocytogenes in a noncontrolled environment. BMC Genomics 9:539. doi: 10.1186/1471-2164-9-539

Osman, K. M., Samir, A., Orabi, A., and Zolnikov, T. R. (2014). Confirmed low prevalence of Listeria monocytogenes in she-camel milk delivers a safe, alternative milk for human consumption. Acta Trop. 130, 1-6. doi: 10.1016/j.actatropica.2013.10.001

Ottaviani, F., Ottaviani, M., and Agosti, M. (1997). Esperienza su un agar selettivo e differentiale per Listeria monocytogenes. Ind. Alimentarius 36, 1-3.

Pangallo, D., Kaclikova, E., Kuchta, T., and Drahovska, H. (2001). Detection of Listeria monocytogenes by polymerase chain reaction oriented to inlB gene. New Microbiol. 24, 333-339.

Park, S. H., Chang, P. S., Ryu, S., and Kang, D. H. (2014). Development of a novel selective and differential medium for the isolation of Listeria monocytogenes. Appl. Environ. Microbiol. 80, 1020-1025. doi: 10.1128/AEM.02840-13

Pichler, J., Appl, G., Pietzka, A., and Allerberger, F. (2011). Lessons to be learned from an outbreak of foodborne Listeriosis, Austria 2009-2010. Food Prot. Trends 31, 268-273.

Pinto, M., Burri, S., Mena, C., Almeida, G., Carneiro, L., Teixeira, P., et al. (2001). Comparison of Oxford Agar, PALCAM and Listeria monocytogenes Blood Agar for the recovery of $L$. monocytogenes from foods and environmental samples. Food Control 12, 511-514. doi: 10.1016/S0956-7135(01)00052-4

Rantsiou, K., Alessandria, V., Urso, R., Dolci, P., and Cocolin, L. (2008). Detection, quantification and vitality of Listeria monocytogenes in food as determined by quantitative PCR. Int. J. Food Microbiol. 121, 99-105. doi: 10.1016/j.ijfoodmicro.2007.11.006

Rawool, D. B., Malik, S. V. S., Barbuddhe, S. B., Shakuntala, I., and Aurora, R. (2007). A multiplex PCR for detection of virulence associated genes in Listeria monocytogenes. Int. J. Food Saf. 9, 56-62.

Reddy, T. B., Thomas, A. D., Stamatis, D., Bertsch, J., Isbandi, M., Jansson, J., et al. (2015). The Genomes OnLine Database (GOLD) v.5: a metadata management system based on a four level (meta) genome project classification. Nucleic Acids Res. 43:D1099-106. doi: 10.1093/nar/gku950

Reuter, S., Ellington, M. J., Cartwright, E. J., Köser, C. U., Török, M. E., Gouliouris, T., et al. (2013). Rapid bacterial whole-genome sequencing to enhance diagnostic and public health microbiology. JAMA Intern. Med. 173, 1397-1404. doi: 10.1001/jamainternmed.2013.7734

Rodríguez-Lázaro, D., Hernández, M., and Pla, M. (2004). Simultaneous quantitative detection of Listeria spp. and Listeria monocytogenes using a duplex real-time PCR-based assay. FEMS Microbiol. Lett. 233, 257-267. doi: 10.1111/j.1574-6968.2004.tb09490.x

Rossmanith, P., Krassnig, M., Wagner, M., and Hein, I. (2006). Detection of Listeria monocytogenes in food using a combined enrichment/real-time PCR method targeting the prfA gene. Res. Microbiol. 157, 763-771. doi: 10.1016/j.resmic.2006.03.003

Rudol, M., and Scherer, S. (2001). High incidence of Listeria monocytogenes in European red smear cheese. Int. J. Food Microbiol. 63, 91-98. doi: 10.1016/S0168-1605(00)00413-X

Rychli, K., Müller, A., Zaiser, A., Schoder, D., Allerberger, F., Wagner, M., et al. (2014). Genome sequencing of Listeria monocytogenes "Quargel" listeriosis outbreak strains reveals two different strains with distinct in vitro virulence potential. PLoS ONE 9:e89964. doi: 10.1371/journal.pone.0089964

Ryu, J., Park, S. H., Yeom, Y. S., Shrivastav, A., Lee, S. H., Kim, Y. R., et al. (2013). Simultaneous detection of Listeria species isolated from meat processed foods using multiplex PCR. Food Control 32, 659-664. doi: 10.1016/j.foodcont.2013.01.048

Sabat, A. J., Budimir, A., Nashev, D., Sá-Leão, R., Van Dijl, J. M., Laurent, F., et al. (2013). Overview of molecular typing methods for outbreak detection and epidemiological surveillance. Euro. Surveill. 18:20380.

Sallen, B., Rajoharison, A., Desvarenne, S., Quinn, F., and Mabilat, C. (1996). Comparative analysis of $16 \mathrm{~S}$ and 23S rRNA sequences of Listeria species. Int. J. Syst. Bacteriol. 46, 669-674. doi: 10.1099/00207713-46-3-669

Salvat, G., and Fravalo, P. (2004). Risk assessment strategies for Europe: integrated safety or final product control: example of Listeria monocytogenes in processed products from pork meat industry. Dtsch. Tierarztl. Wochenschr. 111, 331-334.

Sanger, F., Nicklen, S., and Coulson, A. R. (1977). DNA sequencing with chainterminating inhibitors. Proc. Natl. Acad. Sci. U.S.A. 74, 5463-5467. doi: 10.1073/pnas.74.12.5463
Severgnini, M., Cremonesi, P., Consolandi, C., De Bellis, G., and Castiglioni, B. (2011). Advances in DNA microarray technology for the detection of foodborne pathogens. Food Bioprocess. Technol. 4, 936-953. doi: 10.4061/2011/310135

Shan, X., Zhang, Y., Zhang, Z., Chen, M., Su, Y., Yuan, Y., et al. (2012). Rapid detection of food-borne Listeria monocytogenes by real-time quantitative loopmediated isothermal amplification. Food Sci. Biotechnol. 21, 101-106. doi: 10.1007/s10068-012-0012-6

Shendure, J., and Ji, H. (2008). Next-generation DNA sequencing. Nat. Biotechnol. 26, 1135-1145. doi: $10.1038 /$ nbt1486

Simon, M. C., Gray, D. I., and Cook, N. (1996). DNA extraction and PCR methods for the detection of Listeria monocytogenes in cold-smoked salmon. Appl. Environ. Microbiol. 62, 822-824.

Simpkins, S. A., Chan, A. B., Hays, J., Pöpping, B., and Cook, N. (2000). An RNA transcription-based amplification technique (NASBA) for the detection of viable Salmonella enterica. Lett. Appl. Microbiol. 30, 75-79. doi: 10.1046/j.1472765x.2000.00670.x

Smith, M. A., Takeuchi, K., Brackett, R. E., McClure, H. M., Raybourne, R. B., Williams, K. M., et al. (2003). Nonhuman primate model for Listeria monocytogenes-induced stillbirths. Infect. Immun. 71, 1574-1579. doi: 10.1128/IAI.71.3.1574-1579.2003

Stone, S. C., and Shoenberger, J. (2001). Update: multistate outbreak of listeriosis - United States, 2000. Ann. Emerg. Med. 38, 339-341. doi: 10.1067/mem.2001.117781

Suo, B., He, Y., Paoli, G., Gehring, A., Tu, S. I., and Shi, X. (2010). Development of an oligonucleotide-based microarray to detect multiple foodborne pathogens. Mol. Cell. Probes 24, 77-86. doi: 10.1016/j.mcp.2009.10.005

Sutton, S. (2010). The most probable number method and its uses in enumeration, qualification, and validation. Microbiol. Top. 16, 35-38.

Swetha, C. S., Madhava Rao, T., Krishnaiah, N., and Vijaya Kumar, A. (2012). Detection of Listeria monocytogenes in fish samples by PCR assay. Ann. Biol. Res. 3, 1880-1884.

Tang, M. J., Zhou, S., Zhang, X. Y., Pu, J. H., Ge, Q. L., Tang, X. J., et al. (2011). Rapid and sensitive detection of Listeria monocytogenes by loop-mediated isothermal amplification. Curr. Microbiol. 63, 511-516. doi: 10.1007/s00284-0110013-3

USDA-FSIS (2013). Isolation and Identification of Listeria monocytogenes from Red Meat, Poultry and Egg Products, and Environmental Samples. Effective January, 2013 MLG 8.09. Available at: http://www.fsis.usda.gov/wps/wcm/connect/ 1710bee8-76b9-4e6c-92fc-fdc290dbfa92/MLG-8.pdf?MOD=AJPERES [accessed May 16, 2015].

Uyttendaele, M., Schukkink, R., van Gemen, B., and Debevere, J. (1995). Development of $\mathrm{NASBA}^{\circledR}$, a nucleic acid amplification system, for identification of Listeria monocytogenes and comparison to ELISA and a modified FDA method. Int. J. Food Microbiol. 27, 77-89. doi: 10.1016/0168-1605(95)00166-H

Välimaa, A. L., Tilsala-Timisjärvi, A., and Virtanen, E. (2015). Rapid detection and identification methods for Listeria monocytogenes in the food chain - a review. Food Control55, 103-114. doi: 10.1016/j.foodcont.2015.02.037

Van Netten, P., Perales, I., van de Moosdijk, A., Curtis, G. D. W., and Mossel, D. A. A. (1989). Liquid and solid selective differential media for the detection and enumeration of L. monocytogenes and other Listeria spp. Int. J. Food Microbiol. 8, 299-316. doi: 10.1016/0168-1605(89)90001-9

Vlaemynck, G., Lafarge, V., and Scotter, S. (2000). Improvement of the detection of Listeria monocytogenes by the application of ALOA, a diagnostic, chromogenic isolation medium. J. Appl. Microbiol. 88, 430-441. doi: 10.1046/j.13652672.2000.00978.x

Volokhov, D., Rasooly, A., Chumakov, K., and Chizhikov, V. (2002). Identification of Listeria species by microarray-based assay. J. Clin. Microbiol. 40, 4720-4728. doi: 10.1128/JCM.40.12.4720-4728.2002

Wan, C., Yang, Y., Xu, H., Aguilar, Z. P., Liu, C., Lai, W., et al. (2012). Development of a propidium monoazide treatment combined with loopmediated isothermal amplification (PMA-LAMP) assay for rapid detection of viable Listeria monocytogenes. Int. J. Food Sci. Technol. 47, 2460-2467. doi: 10.1111/j.1365-2621.2012.03123.x

Wang, D. G., Brewster, J. D., Paul, M., and Tomasula, P. M. (2015). Two methods for increased specificity and sensitivity in loop-mediated isothermal amplification. Molecules 20, 6048-6059. doi: 10.3390/molecules200 46048 
Wang, D., Zhang, G., Lu, C., Deng, R., Zhi, A., Guo, J., et al. (2011). Rapid detection of Listeria monocytogenes in raw milk with loop-mediated isothermal amplification and chemosensor. J. Food Sci. 76, M611-M615. doi: 10.1111/j.1750-3841.2011.02383.x

Wang, R. F., Cao, W. W., and Johnson, M. G. (1992). 16S rRNA-based probes and polymerase chain reaction method to detect Listeria monocytogenes cells added to foods. Appl. Environ. Microbiol. 58, 2827-2831.

Wang, X. M., Lü, X. F., Yin, L., Liu, H. F., Zhang, W. J., Si, W., et al. (2013). Occurrence and antimicrobial susceptibility of Listeria monocytogenes isolates from retail raw foods. Food Control 32, 153-158. doi: 10.1016/j.foodcont.2012.11.032

Wernars, K., Heuvelman, C. J., Chakraborty, T., and Notermans, S. H. W. (1991). Use of the polymerase chain reaction for direct detection of Listeria monocytogenes in soft cheese. J. Appl. Bacteriol. 70, 121-126. doi: 10.1111/j.1365-2672.1991.tb04437.x

Winters, D. K., Maloney, T. P., and Johnson, M. G. (1999). Rapid detection of Listeria monocytogenes by a PCR assay specific for an aminopeptidase. Mol. Cell. Probes 13, 127-131. doi: 10.1006/mcpr.1999.0224

Wu, R., Liu, X., Guo, B., Chen, F., and Wang, X. (2014). Development of double loop-mediated isothermal amplification to detect Listeria monocytogenes in food. Curr. Microbiol. 69, 839-845. doi: 10.1007/s00284-014-0661-1

Yang, Y., Xu, F., Xu, H., Aguilar, Z. P., Niu, R., Yuan, Y., et al. (2013). Magnetic nano-beads based separation combined with propidium monoazide treatment and multiplex PCR assay for simultaneous detection of viable Salmonella Typhimurium. Escherichia coli O157:H7 and Listeria monocytogenes in food products. Food Microbiol. 34, 418-424. doi: 10.1016/j.fm.2013. 01.004

Ye, Y., Wang, B., Huang, F., Song, Y., Yan, H., Alam, M. J., et al. (2011). Application of in situ loop-mediated isothermal amplification method for detection of Salmonella in foods. Food Control 22, 438-444. doi: 10.1016/j.foodcont.2010.09.023

Yuan, Y., Xu, W., Zhai, Z., Shi, H., Luo, Y., Chen, Z., et al. (2009). Universal primer-multiplex PCR approach for simultaneous detection of Escherichia coli, Listeria monocytogenes, and Salmonella spp. in food samples. J. Food Sci. 74, M446-M452. doi: 10.1111/j.1750-3841.2009.01321.x
Zarei, M., Maktabi, S., and Ghorbanpour, M. (2012). Prevalence of Listeria monocytogenes, Vibrio parahaemolyticus, Staphylococcus aureus, and Salmonella spp. in seafood products using multiplex polymerase chain reaction. Foodborne Pathog. Dis. 9, 108-112. doi: 10.1089/fpd. 2011.0989

Zeng, H., Zhang, X., Sun, Z., and Fang, W. (2006). Multiplex PCR identification of Listeria monocytogenes isolates from milk and milkprocessing environments. J. Sci. Food Agric. 86, 367-371. doi: 10.1002/jsfa. 2352

Zhang, D., Zhang, H., Yang, L., Guo, J., Li, X., and Feng, Y. (2009). Simultaneous detection of Listeria monocytogenes, Staphylococcus aureus, Salmonella enterica and Escherichia coli O157:H7 in food samples using multiplex PCR method. J. Food Saf. 29, 348-363. doi: 10.1111/j.1745-4565.2009.00 161.x

Zhao, X., Lin, C. W., Wang, J., and Oh, D. H. (2014). Advances in rapid detection methods for foodborne pathogens. J. Microbiol. Biotechnol. 24, 297-312. doi: 10.4014/jmb.1310.10013

Zhou, X., and Jiao, X. (2005). Polymerase chain reaction detection of Listeria monocytogenes using oligonucleotide primers targeting actA gene. Food Control 16, 125-130. doi: 10.1016/j.foodcont.2004.01.001

Zunabovic, M., Domig, K. J., and Kneifel, W. (2011). Practical relevance of methodologies for detecting and tracing of Listeria monocytogenes in ready-toeat foods and manufacture environments - a review. LWT-Food Sci. Technol. 44, 351-362. doi: 10.1016/j.lwt.2010.08.005

Conflict of Interest Statement: The authors declare that the research was conducted in the absence of any commercial or financial relationships that could be construed as a potential conflict of interest.

Copyright (c) 2015 Law, Ab Mutalib, Chan and Lee. This is an open-access article distributed under the terms of the Creative Commons Attribution License (CC BY). The use, distribution or reproduction in other forums is permitted, provided the original author(s) or licensor are credited and that the original publication in this journal is cited, in accordance with accepted academic practice. No use, distribution or reproduction is permitted which does not comply with these terms. 